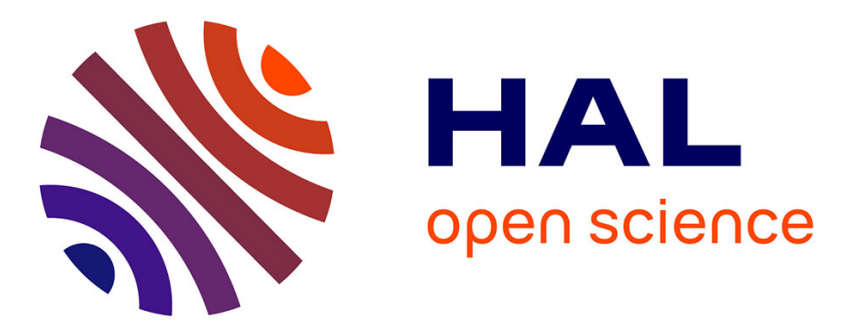

\title{
Geochemistry of the Cambrian Sirius Passet Lagerstatte, Northern Greenland
}

Francis Albarede, Ange Le Boudec, Jon Ineson, Minik Rosing, Lasse Dossing, Francois Martineau, Christophe Lecuyer

\section{- To cite this version:}

Francis Albarede, Ange Le Boudec, Jon Ineson, Minik Rosing, Lasse Dossing, et al.. Geochemistry of the Cambrian Sirius Passet Lagerstatte, Northern Greenland. Geochemistry, Geophysics, Geosystems, 2014, 15 (4), pp.886-904. 10.1002/2013GC005068 . hal-02350699

\section{HAL Id: hal-02350699 \\ https://univ-lyon1.hal.science/hal-02350699}

Submitted on 20 Dec 2021

HAL is a multi-disciplinary open access archive for the deposit and dissemination of scientific research documents, whether they are published or not. The documents may come from teaching and research institutions in France or abroad, or from public or private research centers.
L'archive ouverte pluridisciplinaire HAL, est destinée au dépôt et à la diffusion de documents scientifiques de niveau recherche, publiés ou non, émanant des établissements d'enseignement et de recherche français ou étrangers, des laboratoires publics ou privés.

$$
\text { Copyright }
$$




\section{Geochemistry, Geophysics, Geosystems}

\section{RESEARCH ARTICLE Geochemistry of the Cambrian Sirius Passet Lagerstätte, 10.1002/2013GC005068 Northern Greenland}

Key Points:

- Geochemistry of one of the most important Lagerstätte

- Cambrian explosion triggered by wind-blown fertilization of the ocean

- Continent assembly and high tectonic plateaus are part of biogeochemical cycles

Supporting Information: - Read me

- Supplement Table 1

\section{Correspondence to:}

F. Albarède,

francis.albarede@ens-lyon.fr

Citation:

Le Boudec, A., J. Ineson, M. Rosing, L. Døssing, F. Martineau, C. Lécuyer, and F. Albarède (2014), Geochemistry of the Cambrian Sirius Passet Lagerstätte, Northern Greenland, Geochem. Geophys. Geosyst., 15, 886-904, doi:10.1002/2013GC005068.

Received 30 SEP 2013

Accepted 22 JAN 2014

Accepted article online 27 JAN 2014

Published online 2 APR 2014 Bernard Lyon 1 and CNRS, Département des Sciences de la Terre, Villeurbanne, France

\section{Introduction}

\author{
Ange Le Boudec ${ }^{1}$, Jon Ineson ${ }^{2}$, Minik Rosing ${ }^{3}$, Lasse Døssing ${ }^{3}$, François Martineau ${ }^{4}$, Christophe \\ Lécuyer $^{4}$, and Francis Albarède ${ }^{1}$
}

${ }^{1}$ Ecole Normale Supérieure de Lyon and CNRS, Lyon, France, ${ }^{2}$ Geological Survey of Denmark and Greenland, Copenhagen, Denmark, ${ }^{3}$ Natural History Museum of Denmark, University of Copenhagen, Copenhagen, Denmark, ${ }^{4}$ Université Claude

\begin{abstract}
The lower Cambrian Sirius Passet Lagerstätte ( $\sim 518 \mathrm{Ma})$ consists of mudstones about $8 \mathrm{~m}$ thick located in the Franklinian Basin of North Greenland. We analyzed major and trace elements plus the S, C, $\mathrm{Cu}, \mathrm{Fe}, \mathrm{Zn}$, and Mo isotope compositions. Factor analysis allowed the lithology of the mudstone to be broken down into variable proportions of two inputs, a dry felsic component and a hydrous mafic component (smectite or chlorite). Zircons U-Pb ages indicate multiple sources, the local Proterozoic basement of Northern Greenland (1250-2400 Ma) and Pan-African felsic magmas (620-650 Ma) from across the lapetus ocean. Diagenesis involved the reduction of $\mathrm{Fe}, \mathrm{S}$, and $\mathrm{Mo}$ from seawater and pyritization. The Sirius Passet Lagerstätte formed in oxygen-starved muds inhibiting degradation of organic matter underneath a wellventilated water column. The chemistry of the samples, their very fine grain size, their apparent lack of graded bedding, and the age of zircons suggest that the Lagerstätte may represent wind-blown dust deposited on the continental slope.
\end{abstract}

Lagerstätten are sedimentary sequences of fine-grained shales in which preservation of fossil biota inclusive of soft tissues is exceptionally good [Seilacher et al., 1985]. The Lagerstätten provide the best documentation of the Cambrian explosion of Metazoan. The most remarkable are the Burgess Shale-type (BST) deposits, which are typified by the deposit of British Columbia. They include the Maotianshan (Chengjiang) Shales in the Yunnan [Luo et al., 1997; Zhang and Hou, 1985], the Emu Bay Shale in South Australia [Nedin, 1995], and Sirius Passet in North Greenland [Morris et al., 1987], the focus of this work. Allison and Briggs [1993] pointed out that Lagerstätten fauna are overrepresented in the fossil record and that BST are largely characteristic of the Cambrian. A major conundrum is whether the local BST Lagerstätte sedimentary environment was instrumental in the evolution of these faunas, or simply permitted the exceptional preservation of their fossils. A paradoxical aspect of BST deposits is that large benthic animals clearly in need of oxygen for respiration are found within sedimentary sequences in which the existence of fine laminations demonstrates a lack of bioturbation [Mangano et al., 2012] and therefore the suboxic or anoxic nature of the diagenetic environment [Gaines et al., 2005]. At first sight, the presence of sulfides and the preservation of organic material suggest that they may share common characteristics with sediments from hypoxic, anoxic, or euxinic (e.g., sulfur-rich) environments, or even possibly with black shales, which are rich in organic carbon and metals. It is not clear that the occurrence of Lagerstätten records stable environmental conditions, rather than a particular set of dynamic conditions, such as a fluctuating oxycline [Allison and Brett, 1995; Steiner et al., 2005], the proliferation of microbial faunas or algal mats favorable to fossil preservation [Cai et al., 2012; Gaines and Droser, 2005; Gaines et al., 2012; Gehling, 1999; Petrovich, 2001] or simply the serendipitous occurrence of preservational traps for animals transported from adjacent areas [Gaines and Droser, 2005; Morris, 1986; Zhang and Hou, 2007; Zhang et al., 2006].

We therefore dedicated the present work to investigating the geochemistry of the Sirius Passet Lagerstätte, including major and trace elements plus stable isotope tracers. The Sirius Passet fauna belong in a group of middle Cambrian Lagerstätten (stage 3 ) age ( 518 Ma) [Zhu et al., 2006]. The fauna is preserved in a finegrained slope mudstone succession located in the Cambrian Buen Formation of the Franklinian Basin, a Neoproterozoic-Palaeozoic basin deformed in the Ellesmerian orogeny ( 400 Ma) that stretches across northern Greenland and Arctic Canada. 
The first part of the present work consists of assessing the nature and origin of the sediments, which was done by applying factor analysis to major and trace element data. We measured the isotopic abundances of $\mathrm{C}, \mathrm{S}, \mathrm{Fe}, \mathrm{Zn}, \mathrm{Cu}$, and Mo. We also assessed the abundances of highly reactive elements, i.e., those which react at ambient temperature with sulfides and other ligands and can be extracted by partial dissolution of the sediment [Canfield, 1989; Leventhal and Taylor, 1990; Raiswell et al., 1994] and broke down the results into components and evaluated how they correlate with isotopic variability and with trace elements, such as Mo, Co, and V, widely used to characterize hypoxic, anoxic, or euxinic environments. As an attempt to constrain the source of the sediments, we also acquired $\mathrm{U}-\mathrm{Pb}$ ages on some detrital zircons present in the mudstones by using SIMS.

\section{Geology}

At the transition from the Precambrian to the Cambrian, there is general agreement that Greenland was part of Laurentia, situated in the southern hemisphere near the equator under arid or tropical climate [Cocks and Torsvik, 2011; Hoffman, 1991; McCausland et al., 2007; McKerrow et al., 1992]. Shallow seas covered much of the craton. Greenland, the position of which corresponds to the present north-eastern corner of the North American shield, was then bordered by two opening oceans: the lapetus Ocean to the east of present day Greenland, and some unnamed oceanic zone between the Panthalassic Ocean and the lapetus Ocean to the north. Although the timing is poorly constrained, the east-west-trending Franklinian Basin, now preserved along the Arctic shores, probably originated from rifting in latest Proterozoic times. Deposition in this basin in North Greenland can be considered as taking place along a passive continental margin, evolving in two discrete elements at least until the Early Silurian, a broad marine shelf flanking the Precambrian craton in the southern part, and a deep-water basin or trough in the northern part [Higgins et al., 1991; Hurst and Surlyk, 1983]. The shelf-basin system broke down in the Early Silurian when the shelf foundered and the basinal strata expanded southward.

Higgins et al. [1991] and Ineson et al. [2011] defined two main stages of basin evolution, recorded by five major sedimentary units, in the late Proterozoic-Early Cambrian period. First, a basin initiation and shelftrough differentiation stage, including (Figure 1): (i) the Skagen Group, composed of marine carbonates and siliciclastics [Surlyk and Ineson, 1987]; (ii) the Portfjeld Formation, a carbonate platform conformably overlying the Skagen Group [Higgins et al., 1991]; (iii) the Paradisfjeld Group, the slope and basinal equivalent of the Portfjeld Formation, composed of a heterogeneous succession of dark siliciclastic and carbonate mudstones, carbonate turbidites, and debris flow conglomerates. The transgressive stage includes: (i) the Buen Formation, overlying the Portfjeld Formation, consisting of a siliciclastic shelf succession [Higgins et al., 1991; Ineson and Peel, 1997], and (ii) the Polkorridoren Group, the basinal equivalent of the Buen Formation, overlying the Paradisfjeld Group, represented by mudstone units associated with thin-bedded sandstone turbidites, alternating with units dominated by thick-bedded sandstone turbidites.

\subsection{Sirius Passet Area}

The fossiliferous slope mudstones of the Sirius Passet Lagerstätte occur next to the Buen thrust in northeastern Peary Land; this structural feature juxtaposes the Paradisfjeld-Polkorridoren groups (Cambrian trough) to the north with the Portfjeld-Buen formations (Neoproterozoic-Cambrian shelf) to the south. The slope facies at this important palaeogeographic and structural boundary are referred to the mainly shelfal Buen Formation (the transitional Buen Formation of Ineson and Peel [2011]). Although the vast majority of the fauna has been recovered from the main outcrop and associated scree (Locality 1 of Ineson and Peel [2011, p. 65]), six fossiliferous localities are reported within a $1 \mathrm{~km}$ long window [Peel and Ineson, 2011]. According to Ineson and Peel [2011], four facies coexist in this area: fossiliferous dark gray laminated mudstones, dark-gray bioturbated mudstones, bioturbated and turbiditic sandstones, and carbonate breccia beds and olistoliths. So far, some 40 species have been described from the Sirius Passet fauna [Peel, 2010]. Among them, Buenullus higginsi Blaker [1988] suggests a stratigraphic correlation with the Nevadella Zone in Laurentia [Blaker and Peel, 1997], equivalent to Stage 3 of the Cambrian (ca. 514-521 Ma). Fossil assemblages are characterized by a predominance of arthropods and lobopods (mainly biomineralized), "upsidedown" trilobites, occasionally slightly deformed by compaction and low-grade metamorphism, fine burrow preservation, some horizons including abundant invertebrates, and varying degrees of soft-part preservation [Babcock and Peel, 2007; Mangano et al., 2012; Peel, 2010]. 

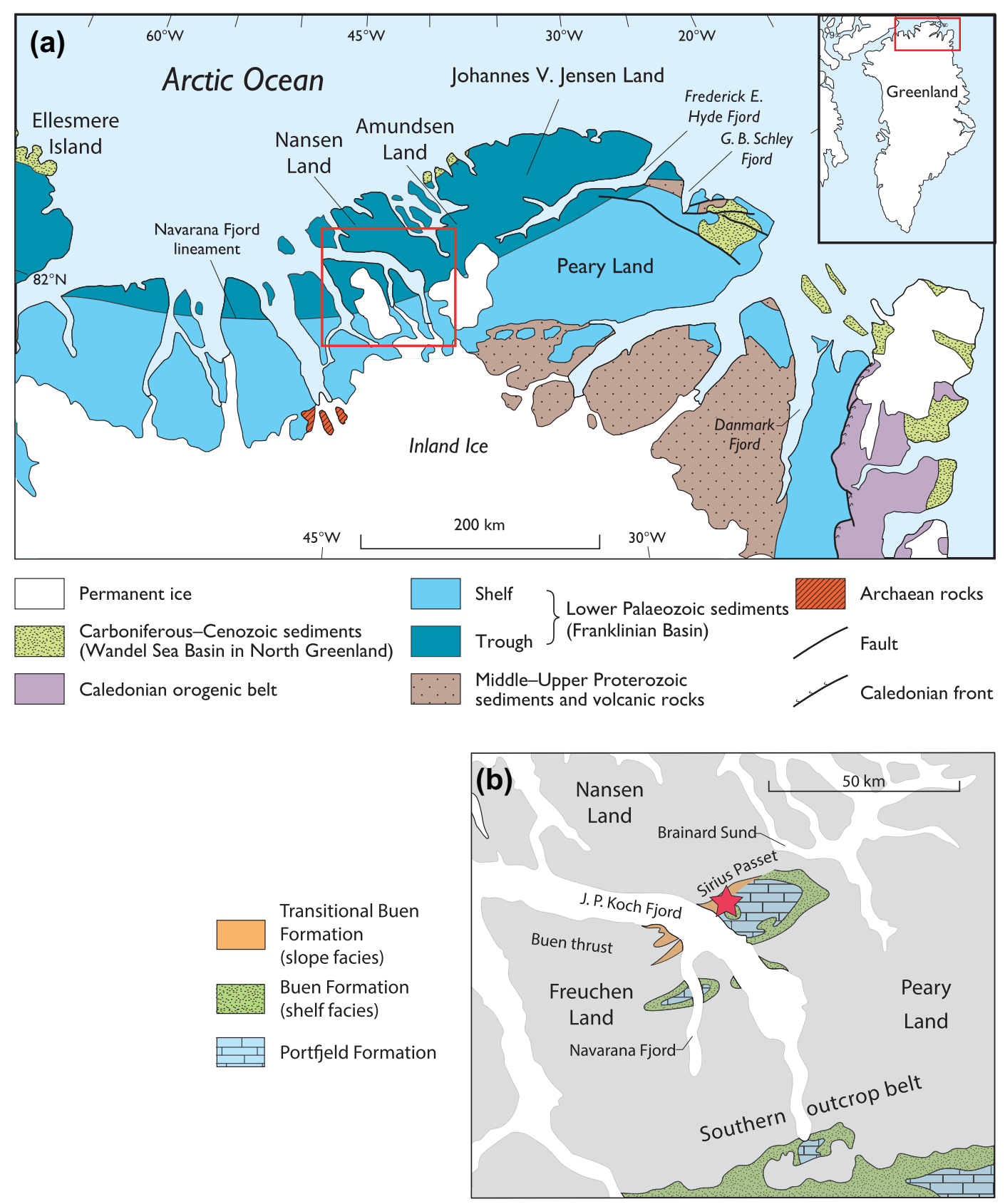

Figure 1. Location of the Sirius Passet Lagerstätte in North Greenland. (a) Map of the lower Palaeozoic Franklinian Basin in northern Greenland showing the subdivision of the basin into the southern shelf and the northern deeper water trough. The shelf-basin boundary shown here is representative of the Ordovician-Silurian position at the Navarana Fjord lineament, the boundary being farther north during the Cambrian. The outlined area is that shown in Figure 1b. (b) Geological sketch map of the central portion of North Greenland showing the distribution of Cambrian stratigraphic units relevant to this paper. The Sirius Passet fossil locality (red star) is located in the outlined area, east of J.P. Koch Fjord, straddling the tectonic and palaeogeographic transition between Cambrian deposits of the deep-water basin and the shelf. Redrawn from Ineson and Peel [2011].

The section comprises an alternation of fossiliferous finely laminated mudstones, and of more or less weakly laminated mudstones associated with bioturbation. Although it was initially suggested on the base of trilobite orientations that the series is upside down [Ineson and Peel, 2011], we now consider that the relative abundance of upside-down fossils is not really significant and assume that the bottom-top section reflects the sequence of deposition. 


\section{Analytical Techniques}

Samples were coarsely crushed in a percussion mortar and any visibly altered part removed. The coarse fraction was transferred to an agate mortar for gentle pulverization. Elemental concentrations were measured by XRF in Copenhagen for major elements, and by quadrupole ICP-MS (Agilent $7500 \mathrm{CX}$ ) in Lyon for concentration levels $<100$ ppm. The Mo, Cu, Zn, Fe isotope compositions were analyzed on a Nu-Instruments MC-ICP-MS Nu HR, and C and $\mathrm{S}$ isotope compositions on EA-IRMS in Lyon. All commercial reagents but $\mathrm{HClO}_{4}$ were purified in a Teflon still.

\subsection{Bulk Concentration}

In order to eliminate organic matter, $\sim 0.5 \mathrm{~g}$ of sample powder was heated for $\sim 12 \mathrm{~h}$ at $550^{\circ} \mathrm{C}$ in a muffle furnace. The loss-on-ignition (LOI) was obtaining by comparing weights before and after the calcination step. Then, the samples were transferred into PFA beakers and leached in $6 \mathrm{~mL}$ of $6 \mathrm{~N} \mathrm{HCl}$ at $140^{\circ} \mathrm{C}$ for at least $6 \mathrm{~h}$. After centrifugation, $\mathrm{HCl}$ was drained and saved in another beaker. The solid residue was dissolved in $6 \mathrm{~mL}$ of concentrated HF/ $6 \mathrm{~N} \mathrm{HCl}(1: 1)$ kept at $160^{\circ} \mathrm{C}$ for $\sim 12 \mathrm{~h}$. These residual parts were evaporated to dryness at $110^{\circ} \mathrm{C}$. The next step consisted in digesting any residual kerogen in $0.5 \mathrm{~mL}$ of concentrated $\mathrm{HClO}_{4} / \mathrm{HNO}_{3}(1: 2)$ at $180^{\circ} \mathrm{C}$ for at least $4 \mathrm{~h}$, and evaporating the solution again to dryness. The residue was redissolved in $6 \mathrm{~N} \mathrm{HCl}$, combined with the saved $\mathrm{HCl}$ leach, reevaporated at $110^{\circ} \mathrm{C}$, and redissolved in dilute $\mathrm{HNO}_{3}$. Elements were analyzed on a $\sim 10 \%$ aliquot that was further diluted in $2 \% \mathrm{HNO}_{3}$. Internal standards (10 ppm Sc for ICP-AES and $2 \mathrm{ppb}$ In for Q-ICP-MS) were added. The other $90 \%$ were evaporated to dryness and entered for the analysis of iron, zinc, and copper isotopes.

\subsection{Sulfur Concentrations}

Fifty milligrams of bulk samples were leached in $\sim 10 \mathrm{~mL}$ of boiling aqua regia at $110^{\circ} \mathrm{C}$ for $\sim 12 \mathrm{~h}$. After centrifugation, solution aliquots were subsequently diluted in $2 \% \mathrm{HNO}_{3}+10 \mathrm{ppm}$ scandium as internal standard and analyzed on Q-ICP-MS.

\subsection{Highly Reactive Elements}

About $0.2 \mathrm{~g}$ of powdered samples was cold-leached with $20 \mathrm{~mL}$ of $1 \mathrm{~N} \mathrm{HCl}$ for $24 \mathrm{~h}$ [Leventhal and Taylor, 1990; Raiswell et al., 1994]. Solutions aliquots were then directly diluted in $2 \% \mathrm{HNO}_{3}+$ internal standard for analysis on ICP-AES or Q-ICP-MS.

\subsection{Iron, Zinc, and Copper Purification}

$\mathrm{Fe}, \mathrm{Zn}$, and Cu were separated using standard methods [Maréchal et al., 1999]. Briefly, samples were redissolved in $1 \mathrm{~mL}$ of $7 \mathrm{~N} \mathrm{HCl}+0.001 \% \mathrm{H}_{2} \mathrm{O}_{2}$ by sonication and loaded on a $20 \mathrm{~mL}$ quartz column containing $1.6 \mathrm{~mL}$ of preconditioned AG MP-1 anion exchange resin. First, major elements were eluted with $10 \mathrm{~mL}$ of 7 $\mathrm{N} \mathrm{HCl}+0.001 \% \mathrm{H}_{2} \mathrm{O}_{2}$, then copper, iron, and zinc were sequentially removed with $20 \mathrm{~mL}$ of $7 \mathrm{~N}$ $\mathrm{HCl}+0.001 \% \mathrm{H}_{2} \mathrm{O}_{2}, 10 \mathrm{~mL}$ of $2 \mathrm{~N} \mathrm{HCl}+0.001 \% \mathrm{H}_{2} \mathrm{O}_{2}$, and $10 \mathrm{~mL}$ of $0.5 \mathrm{~N} \mathrm{HNO}_{3}$ respectively. Each fraction was finally evaporated to dryness at $105^{\circ} \mathrm{C}$. This process was repeated for $\mathrm{Cu}$ and $\mathrm{Zn}$ fractions in order to minimize any elemental interaction. Yields were $96 \pm 4 \%$.

\subsection{Molybdenum Purification}

The present samples are problematic because their Mo concentrations are low ( $<2 \mathrm{ppm})$ and their Fe concentrations high. A $0.3 \mathrm{~g}$ aliquot of ashed samples was leached three times in boiling concentrated $\mathrm{HCl}$ during cycles of $6 \mathrm{~h}$. Each time, samples were cooled down and centrifuged. Supernatants $\mathrm{HCl}$ were transferred into Teflon beakers and spiked with an appropriate amount of a mixed ${ }^{97} \mathrm{Mo}-{ }^{100} \mathrm{Mo}$ tracer for double-spike analysis. After evaporation to near-dryness at $110^{\circ} \mathrm{C}$, samples were redissolved in $1 \mathrm{~mL} 1 \mathrm{~N} \mathrm{HCl}+0.01 \%$ $\mathrm{H}_{2} \mathrm{O}_{2}$. Concentration measurements on most samples attested that this leaching step removed all (>95\%) Mo from the sediment. The yield of the separation was tested on Mo-free pyrite spiked with 2 ppm Mo from a molybdenum standard plasma solution (Johnson Matthey Chemical). The present chemistry, which is detailed in Table 1, achieves molybdenum purification with Fe/Mo $<1$, making it suitable for isotopic analyses (standard-sample bracketing or SSB) [Albarède, 2004; Maréchal et al., 1999].

Iron isotopic analyses were performed on a large-radius high-resolution Nu-1700 MC-ICPMS using a Nu Instruments DSN-100 desolvating system working with a mass resolution of 3000. Instrumental mass fractionation was corrected by SSB. Chromium interference at mass 54 was corrected, using its natural abundance, by monitoring ${ }^{52} \mathrm{Cr}$. Molybdenum isotope compositions were analyzed on a Nu-500 HR MC-ICPMS using a Nu Instruments DSN100 desolvating system. Chemical and instrumental mass fractionations were corrected using a double-spike [Siebert et al., 2001] but using the equations from Albarède et al. [2004]. The external reproducibility $(2 \sigma)$ was $0.05 \%$ 


\begin{tabular}{|c|c|c|}
\hline Eluent & Volume (mL) & Purpose \\
\hline $4 \mathrm{~N} \mathrm{HNO}_{3}$ & 20 & Resin cleaning \\
\hline Milli-Q water & 5 & Resin cleaning \\
\hline $0.5 \mathrm{~N} \mathrm{HNO}_{3}$ & 10 & Resin cleaning \\
\hline Milli-Q water & 5 & Resin cleaning \\
\hline $1 \mathrm{~N} \mathrm{HCl}+0.01 \% \mathrm{H}_{2} \mathrm{O}_{2}$ & 8 & Resin conditioning \\
\hline $1 \mathrm{~N} \mathrm{HCl}+0.01 \% \mathrm{H}_{2} \mathrm{O}_{2}$ & 1 & Sample load \\
\hline $0.6 \mathrm{~N} \mathrm{HCl}+0.01 \% \mathrm{H}_{2} \mathrm{O}_{2}$ & 50 & $\begin{array}{l}\text { Elution of the bulk } \\
\text { sample matrix }\end{array}$ \\
\hline $0.05 \mathrm{~N} \mathrm{HNO}_{3}+0.03 \mathrm{~N} \mathrm{HF}$ & 10 & $\begin{array}{l}\text { Elution of the residual } \\
\text { sample matrix }\end{array}$ \\
\hline $4 \mathrm{~N} \mathrm{HNO}_{3}+0.03 \mathrm{~N} \mathrm{HF}$ & 40 & Mo elution \\
\hline
\end{tabular}

for the reported $\mathrm{Cu}, \mathrm{Zn}$, and $\mathrm{Fe}$ isotopic ratios, and $0.12 \%$ for Mo isotopic ratio. All samples isotopic data are reported in delta notation relative to an elemental isotopic reference material: "NIST SRM 976" solution (Cu); "JMC 3-0749" solution (Zn); "IRMM14" solution (Fe); "NIST SRM 3134” solution (Mo).

\subsection{Carbon and Sulfur Isotopic Analyses} Given the very low Ca content of samples and their rather high organic fraction, they were not decarbonated before analysis. Between 10 and $50 \mathrm{mg}$ of bulk powdered sample were weighed in silver capsules then combusted and pyrolized at $1450^{\circ} \mathrm{C}$ using a vario PYRO cube analyzer

(purge and trap system) interfaced to an Isotope Ratio Mass Spectrometer (Isoprime). Stable sulfur isotope compositions were determined with respect to three laboratory standards precalibrated against Canyon Diablo Troilite (CDT). Stable carbon isotopic compositions values are reported relative to Pee Dee Belemnite (PDB). Average standard deviation values are $0.36 \%$ for $\delta^{34} \mathrm{~S}$, and $0.2 \%$ for $\delta^{13} \mathrm{C}$.

\subsection{U-Th-Pb Analyses}

Fifty-eight detrital zircons 20-100 $\mu \mathrm{m}$ in size were separated from a Buen sample collected within meters of the fossiliferous beds and mounted for U-Th-Pb analysis. Photographs were taken or the electron backscattered images taken on the JEOL JXA 8200 electron microprobe (EMPA) at the Department of Geosciences and Natural Resource Management in Copenhagen (Figure 2). The isotopic data were generated using a Cameca IMS1270 large-radius ion microprobe at the Nordsim facility, Swedish Museum of Natural History. Detailed analytical methods have been described previously by Whitehouse and Kamber [2005, and references therein].

\section{Results}

Samples were taken along the $8.5 \mathrm{~m}$ main fossiliferous succession of Sirius Passet (latitude $82^{\circ} 47.6^{\prime} \mathrm{N}$, longitude $42^{\circ} 13.7^{\prime} \mathrm{W}$; Locality 1 of Peel and Ineson [2011]. Twenty-five samples were collected at a mean interval

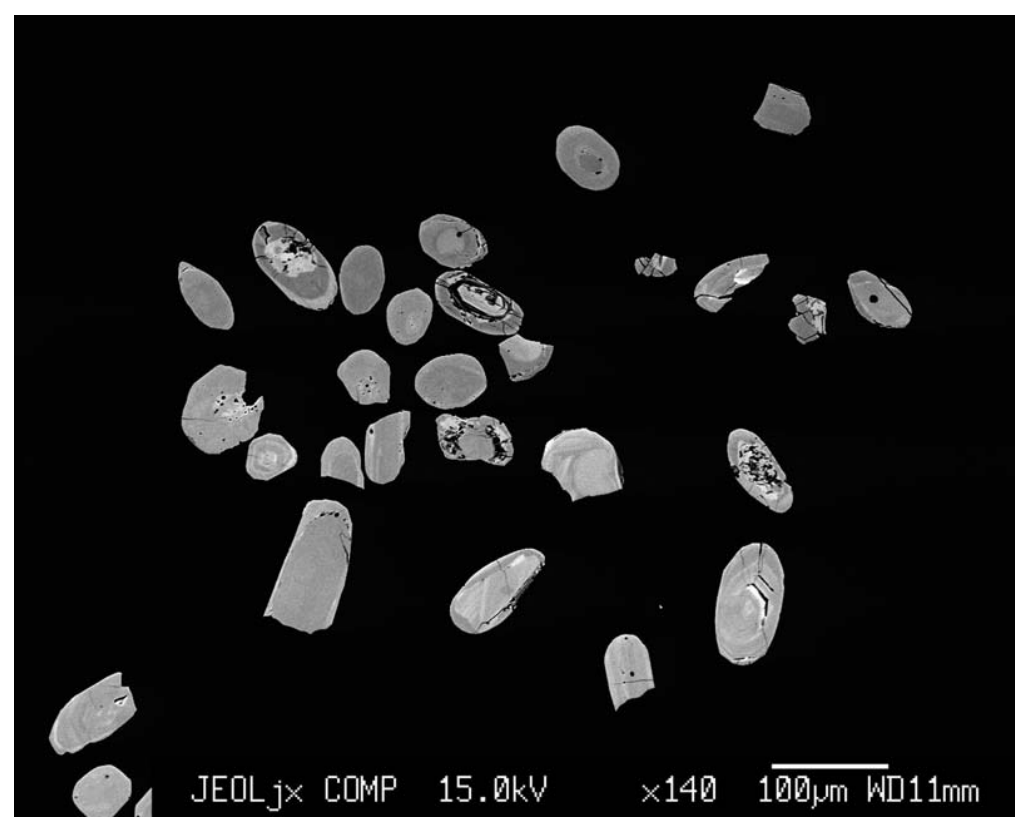

Figure 2. Back-scattered electron images (EMPS) of a representative set of detrital zircons from Sirius Passet mudstones. of $36 \mathrm{~cm}$. One mudstone sample taken from the Buen Formation about $30 \mathrm{~m}$ above the Lagerstätte was also analyzed as a nonfossiliferous reference. Major element, trace element, and isotope composition logs are reported in Tables 2 and 3 and plotted in Figures 3-5. A first characteristic of the geochemical data set is that, with few exceptions, most major and trace elements define a single coherent population. This can be assessed by using QQ-plots [e.g., Johnson and Wichern, 1992], i.e., by comparing the observed quantiles 


\section{QAGU Geochemistry, Geophysics, Geosystems}

$10.1002 / 2013 G C 005068$

Table 2. Summary Data of Geochemical Analyses of Sirius Passet Samples: Loss-Of-Ignition, Major and Trace Elements ${ }^{\mathrm{a}}$

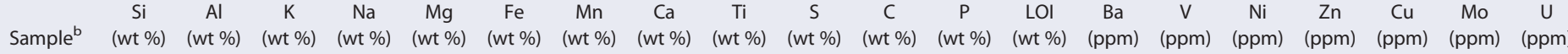

\begin{tabular}{|c|c|c|c|c|c|c|c|c|c|c|c|c|c|c|c|c|c|c|c|c|}
\hline Buen (10) & 25.61 & 15.29 & 3.87 & 0.38 & 1.13 & 4.89 & 0.03 & 0.10 & 0.46 & 0.12 & 1.10 & 0.04 & 4.19 & 531 & 81.5 & 41.3 & 76.8 & 11.01 & 0.15 & 1.62 \\
\hline 0.0 & 26.54 & 15.18 & 3.81 & 0.47 & 0.94 & 4.12 & 0.04 & 0.07 & 0.46 & 0.05 & 0.80 & 0.04 & 3.67 & 690 & 82.8 & 36.5 & 63.0 & 6.13 & 0.16 & 1.42 \\
\hline 0.5 & 26.08 & 16.28 & 3.99 & 0.50 & 0.65 & 3.37 & 0.04 & 0.06 & 0.47 & 0.07 & 1.01 & 0.03 & 3.33 & 758 & 86.7 & 28.8 & 41.0 & 4.14 & 0.33 & 1.57 \\
\hline 0.9 & 25.73 & 13.74 & 3.15 & 0.38 & 1.57 & 7.33 & 0.07 & 0.07 & 0.47 & 0.02 & 0.50 & 0.04 & 4.09 & 506 & 80.5 & 61.5 & 89.8 & 2.98 & 0.13 & 1.16 \\
\hline 1.0 & 25.97 & 15.14 & 3.62 & 0.45 & 1.04 & 5.10 & 0.05 & 0.06 & 0.48 & 0.07 & 0.80 & 0.02 & 4.46 & 629 & 84.7 & 37.4 & 68.4 & 5.19 & 0.30 & 1.32 \\
\hline 1.6 & 25.72 & 14.71 & 3.50 & 0.45 & 1.02 & 5.73 & 0.06 & 0.03 & 0.50 & 0.26 & 1.20 & 0.04 & 4.80 & 594 & 92.5 & 41.5 & 71.8 & 7.10 & 0.35 & 1.89 \\
\hline 1.8 & 26.19 & 14.96 & 3.79 & 0.46 & 0.98 & 4.77 & 0.05 & 0.13 & 0.50 & 0.36 & 0.50 & 0.05 & 4.23 & 639 & 87.4 & 33.8 & 53.6 & 4.96 & 0.65 & 1.61 \\
\hline 2.0 & 25.69 & 14.83 & 3.67 & 0.45 & 1.02 & 5.27 & 0.04 & 0.06 & 0.50 & 0.26 & 1.50 & 0.01 & 5.12 & 647 & 88.8 & 35.5 & 61.0 & 11.10 & 2.05 & 1.57 \\
\hline 2.7 & 24.25 & 13.41 & 2.99 & 0.33 & 1.94 & 9.20 & 0.08 & 0.04 & 0.51 & 0.27 & 1.01 & 0.05 & 5.93 & 412 & 82.4 & 69.8 & 96.9 & 7.65 & 0.31 & 1.79 \\
\hline 3.0 & 24.69 & 16.37 & 3.95 & 0.45 & 0.94 & 4.81 & 0.05 & 0.01 & 0.48 & 0.14 & 1.30 & 0.05 & 4.59 & 626 & 95.7 & 32.2 & 50.8 & 13.51 & 0.33 & 1.85 \\
\hline 3.3 & 25.28 & 16.82 & 4.11 & 0.45 & 0.78 & 3.65 & 0.04 & 0.11 & 0.47 & 0.02 & 0.90 & 0.07 & 4.66 & 700 & 90.5 & 27.0 & 48.1 & 10.33 & 0.19 & 2.12 \\
\hline 3.4 & 26.20 & 13.60 & 3.08 & 0.34 & 1.33 & 6.64 & 0.07 & 0.05 & 0.48 & 0.09 & 1.20 & 0.04 & 5.03 & 464 & 51.2 & 59.5 & 85.4 & 7.96 & 0.13 & 1.39 \\
\hline 4.0 & 27.56 & 16.55 & 4.31 & 0.55 & 0.23 & 1.03 & 0.01 & 0.19 & 0.49 & 0.55 & 0.30 & 0.00 & 3.40 & 815 & 98.9 & 2.7 & 9.1 & 2.09 & 0.38 & 1.31 \\
\hline 4.2 & 24.68 & 13.24 & 2.90 & 0.28 & 2.10 & 9.24 & 0.07 & 0.06 & 0.49 & 0.04 & 0.50 & 0.04 & 4.90 & 392 & 72.1 & 76.7 & 123.4 & 5.83 & 0.14 & 1.45 \\
\hline 4.4 & 25.88 & 14.02 & 3.33 & 0.39 & 1.33 & 6.78 & 0.07 & 0.03 & 0.48 & 0.12 & 0.60 & 0.04 & 4.39 & 522 & 87.0 & 42.9 & 87.8 & 4.59 & 0.10 & 1.68 \\
\hline 5.0 & 26.41 & 16.27 & 3.98 & 0.49 & 0.56 & 3.31 & 0.04 & 0.06 & 0.48 & 0.08 & 0.60 & 0.01 & 3.98 & 614 & 79.8 & 30.1 & 37.5 & 9.28 & 1.04 & 1.79 \\
\hline 5.3 & 26.25 & 16.25 & 3.86 & 0.46 & 0.65 & 3.80 & 0.04 & 0.05 & 0.47 & 0.07 & 0.30 & 0.03 & 3.70 & 682 & 70.9 & 27.6 & 51.6 & 9.76 & 1.03 & 1.47 \\
\hline 5.7 & 25.86 & 15.00 & 3.61 & 0.42 & 1.01 & 5.48 & 0.06 & 0.02 & 0.48 & 0.15 & 0.80 & 0.03 & 4.24 & 578 & 88.4 & 43.3 & 82.3 & 7.72 & 0.43 & 1.68 \\
\hline 6.7 & 27.42 & 15.88 & 4.01 & 0.49 & 0.38 & 2.57 & 0.03 & 0.01 & 0.48 & 0.16 & 0.50 & 0.00 & 3.54 & 682 & 92.9 & 10.9 & 34.5 & 3.77 & 0.77 & 1.67 \\
\hline 7.3 & 25.45 & 14.50 & 3.53 & 0.39 & 1.27 & 6.11 & 0.06 & 0.09 & 0.50 & 0.08 & 1.30 & 0.05 & 4.10 & 525 & 87.1 & 41.8 & 119.0 & 10.92 & 0.18 & 1.65 \\
\hline 7.6 & 24.15 & 13.61 & 3.23 & 0.28 & 2.07 & 8.64 & 0.05 & 0.12 & 0.53 & 0.09 & 1.20 & 0.07 & 5.23 & 403 & 81.3 & 70.1 & 193.0 & 12.43 & 0.16 & 1.69 \\
\hline 8.0 & 25.70 & 16.93 & 4.35 & 0.42 & 0.77 & 2.59 & 0.01 & 0.07 & 0.52 & 0.15 & 1.01 & 0.05 & 4.30 & 600 & 91.4 & 32.2 & 59.2 & 5.53 & 0.24 & 2.19 \\
\hline 8.2 & 26.57 & 13.20 & 3.30 & 0.30 & 1.47 & 6.77 & 0.05 & 0.04 & 0.51 & 0.08 & 0.60 & 0.03 & 4.62 & 422 & 82.0 & 44.8 & 149.7 & 25.47 & 0.18 & 1.49 \\
\hline 8.5 & 24.70 & 12.24 & 2.69 & 0.24 & 2.18 & 9.92 & 0.07 & 0.06 & 0.53 & 0.11 & 1.40 & 0.04 & 5.74 & 317 & 75.1 & 55.4 & 204.7 & 10.88 & 0.13 & 1.49 \\
\hline 8.7 & 26.39 & 12.93 & 3.11 & 0.30 & 1.48 & 7.12 & 0.06 & 0.10 & 0.52 & 0.16 & 1.01 & 0.03 & 4.89 & 384 & 80.1 & 45.1 & 153.9 & 13.84 & 0.14 & 1.55 \\
\hline
\end{tabular}

${ }^{\mathrm{a}}$ Concentrations are in percent (\%) or in part per million (ppm).

${ }^{\mathrm{b}}$ Sample at $2.4 \mathrm{~m}$ was lost. Concentrations are known with a mean uncertainty of $2 \%$ except for LOI (5\%). Extra digits kept for readability.

with those inferred from an a priori distribution, which, as for most geological samples [Allègre and Lewin, 1995], we chose to be lognormal (Figure 6). A single population corresponds to a good alignment along the 1:1 line. Visible exceptions are Mo and S, while the samples located at 4.0 and $6.7 \mathrm{~m}$ tend to be abnormal

Table 3. Summary Data of Geochemical Analyses of Sirius Passet Samples: Abundances of Highly Reactive (HR) Elements and Isotope Compositions

\begin{tabular}{|c|c|c|c|c|c|c|c|c|c|c|c|c|c|c|c|c|c|}
\hline Sample ${ }^{a}$ & $\begin{array}{c}\text { CrHR } \\
(\mathrm{ppm})\end{array}$ & $\begin{array}{l}\text { CoHR } \\
\text { (ppm) }\end{array}$ & $\begin{array}{c}\text { ZnHR\% } \\
\text { (Zn \%) }\end{array}$ & $\begin{array}{l}\text { VHR\% } \\
\text { (V \%) }\end{array}$ & $\begin{array}{c}\mathrm{MnHR} \% \\
(\mathrm{Mn} \%)\end{array}$ & $\begin{array}{c}\mathrm{MgHR} \% \\
(\mathrm{Mg} \%)\end{array}$ & $\begin{array}{c}\mathrm{NiHR} \% \\
(\mathrm{Ni} \%)\end{array}$ & $\begin{array}{c}\text { CuHR\% } \\
\text { (Cu \%) }\end{array}$ & $\begin{array}{c}\text { FeHR\% } \\
(\mathrm{Fe} \%)\end{array}$ & $\begin{array}{c}\text { CaHR\% } \\
\text { (Ca \%) }\end{array}$ & $\begin{array}{c}\text { SHR\% } \\
\text { (S \%) }\end{array}$ & $\begin{array}{l}\delta^{34} \mathrm{~S} \\
(\%)\end{array}$ & $\begin{array}{c}\delta^{56} \mathrm{Fe} \\
(\%)\end{array}$ & $\begin{array}{c}\delta^{66} \mathrm{Zn} \\
(\% \circ)\end{array}$ & $\begin{array}{c}\delta^{65} \mathrm{Cu} \\
(\%)\end{array}$ & $\begin{array}{c}\delta^{98} \mathrm{Mo} \\
(\% \mathrm{oo})\end{array}$ & $\begin{array}{l}\delta^{13} \mathrm{C} \\
(\%)\end{array}$ \\
\hline Buen (10) & 3.9 & 1.5 & 10.2 & 2.1 & 6.8 & 9.4 & 11.1 & 62.1 & 11.1 & 3.6 & 101.2 & 14.16 & 0.43 & 0.14 & 0.18 & -1.19 & -24.69 \\
\hline 0.0 & 3.6 & 0.6 & 7.7 & 1.9 & 4.9 & 9.7 & 12.6 & 64.1 & 10.4 & 4.6 & 60.2 & 18.80 & 0.17 & 0.26 & 0.11 & -0.61 & -22.94 \\
\hline 0.5 & 3.5 & 0.3 & 6.0 & 1.6 & 3.2 & 8.8 & 10.6 & 47.0 & 10.8 & 6.1 & 75.3 & 14.79 & 0.18 & 0.29 & -0.19 & -0.03 & -23.18 \\
\hline 0.9 & 4.3 & 0.5 & 6.6 & 2.1 & 4.8 & 8.9 & 8.9 & 52.0 & 9.6 & 3.6 & 51.7 & 11.94 & 0.22 & 0.23 & 0.04 & -0.67 & -23.33 \\
\hline 1.0 & 3.4 & 0.3 & 6.4 & 2.0 & 3.3 & 8.0 & 8.8 & 53.5 & 10.5 & 7.0 & 74.9 & 13.19 & 0.21 & 0.23 & -0.34 & 0.32 & -22.91 \\
\hline 1.6 & 3.9 & 0.4 & 4.9 & 1.8 & 2.6 & 7.3 & 7.6 & 59.3 & 13.8 & 7.4 & 72.4 & 17.55 & 0.22 & 0.30 & 0.07 & 0.50 & -24.20 \\
\hline 1.8 & 3.9 & 0.2 & 6.2 & 1.8 & 2.9 & 8.7 & 7.8 & 41.9 & 16.0 & 3.8 & 68.2 & 18.88 & 0.33 & 0.22 & -0.31 & 0.17 & -24.23 \\
\hline 2.0 & 4.1 & 0.2 & 6.3 & 1.5 & 4.3 & 8.8 & 7.5 & 23.3 & 9.6 & -1.0 & 51.8 & 13.97 & 0.36 & 0.17 & 0.02 & 0.69 & -23.88 \\
\hline 2.4 & 2.4 & 0.2 & 5.1 & 1.1 & 2.1 & 5.0 & 7.5 & 72.0 & 15.7 & 7.9 & 79.7 & 10.39 & 0.28 & 0.26 & 0.47 & 0.58 & -23.64 \\
\hline 2.7 & 5.9 & 1.0 & 9.5 & 3.5 & 5.4 & 9.9 & 10.7 & 50.8 & 13.4 & 12.0 & 78.3 & 11.54 & 0.22 & 0.29 & 0.31 & -0.19 & -23.10 \\
\hline 3.0 & 4.1 & 0.5 & 6.2 & 1.8 & 4.7 & 7.6 & 9.1 & 51.9 & 19.3 & 15.5 & 100.1 & 13.55 & 0.25 & 0.26 & 0.01 & 0.22 & -22.93 \\
\hline 3.3 & 3.8 & 0.9 & 6.7 & 1.8 & 4.7 & 9.6 & 14.9 & 75.8 & 11.0 & 5.5 & 102.9 & 10.50 & 0.25 & 0.18 & 0.44 & -0.67 & $N A$ \\
\hline 3.4 & 4.3 & 0.6 & 5.4 & 3.2 & 3.4 & 7.7 & 8.2 & 58.0 & 8.4 & 8.9 & 67.4 & 9.86 & 0.23 & 0.25 & -0.04 & -0.61 & -23.63 \\
\hline 4.0 & 1.0 & 0.0 & 0.1 & 0.7 & 1.1 & 5.1 & 8.7 & 60.3 & 11.9 & 4.2 & 40.6 & 15.98 & 0.28 & 0.18 & 0.54 & 0.88 & -27.85 \\
\hline 4.2 & 5.7 & 0.6 & 7.2 & 3.3 & 6.9 & 9.0 & 8.7 & 52.9 & 11.8 & 6.2 & 77.6 & 16.59 & 0.23 & 0.22 & -0.54 & 0.12 & -22.79 \\
\hline 4.4 & 3.2 & 0.5 & 4.0 & 1.6 & 3.6 & 7.5 & 7.4 & 51.4 & 10.1 & 15.7 & 55.4 & 14.57 & 0.18 & 0.19 & -0.23 & -0.31 & -23.50 \\
\hline 5.0 & 2.8 & 0.2 & 3.6 & 1.5 & 2.4 & 9.5 & 9.5 & 21.6 & 12.8 & 9.0 & 63.3 & 13.63 & 0.32 & 0.11 & 0.41 & 0.99 & -24.79 \\
\hline 5.3 & 3.4 & 0.2 & 3.5 & 1.7 & 2.5 & 8.9 & 8.4 & 17.5 & 12.3 & 5.8 & 33.2 & 15.04 & 0.20 & 0.15 & 0.48 & 1.34 & -24.26 \\
\hline 5.7 & 4.1 & 0.2 & 4.4 & 1.7 & 2.8 & 6.2 & 6.9 & 25.8 & 11.2 & 0.9 & 45.9 & 11.69 & 0.30 & 0.20 & -0.63 & -0.05 & -24.97 \\
\hline 6.7 & 1.9 & 0.2 & 5.5 & 0.9 & 1.8 & 7.1 & 11.5 & 42.0 & 9.8 & 12.7 & 19.0 & 21.76 & 0.26 & 0.09 & -0.24 & 0.06 & -24.95 \\
\hline 7.3 & 5.0 & 1.5 & 8.6 & 2.2 & 5.7 & 9.9 & 11.3 & 55.1 & 10.7 & 5.0 & 56.3 & 12.76 & 0.20 & 0.29 & 0.01 & -1.17 & -23.67 \\
\hline 7.6 & 5.5 & 2.8 & 9.9 & 2.9 & 8.4 & 9.6 & 11.3 & 87.0 & 11.3 & 3.7 & 82.4 & 15.17 & 0.15 & 0.13 & -0.11 & -0.77 & $N A$ \\
\hline 8.0 & 3.0 & 0.4 & 7.9 & 1.3 & 7.2 & 7.9 & 7.4 & 53.6 & 13.4 & 2.2 & 40.9 & 23.09 & 0.23 & 0.28 & -0.21 & -0.85 & -23.57 \\
\hline 8.2 & 4.3 & 1.0 & 6.9 & 1.8 & 4.5 & 7.0 & 7.4 & 37.3 & 9.7 & 7.3 & 66.7 & 19.40 & 0.34 & 0.32 & -0.14 & -0.59 & -23.49 \\
\hline 8.5 & 5.5 & 1.4 & 8.4 & 3.1 & 5.3 & 9.2 & 9.1 & 57.9 & 11.0 & 1.9 & 70.6 & 17.68 & 0.35 & 0.35 & 0.25 & -0.43 & -24.05 \\
\hline 8.7 & 4.3 & 0.8 & 7.9 & 2.3 & 4.4 & 8.0 & 7.7 & 64.6 & 10.4 & 3.2 & 67.9 & 18.14 & 0.26 & 0.28 & 0.30 & -0.59 & -24.24 \\
\hline
\end{tabular}

${ }^{a}$ Concentrations on HR variables determined with an uncertainty of $3 \%$ except for $\mathrm{Cr}, \mathrm{Co}, \mathrm{Zn}$, and V (10\%). See text for isotope compositions. 


\section{CAGU Geochemistry, Geophysics, Geosystems}
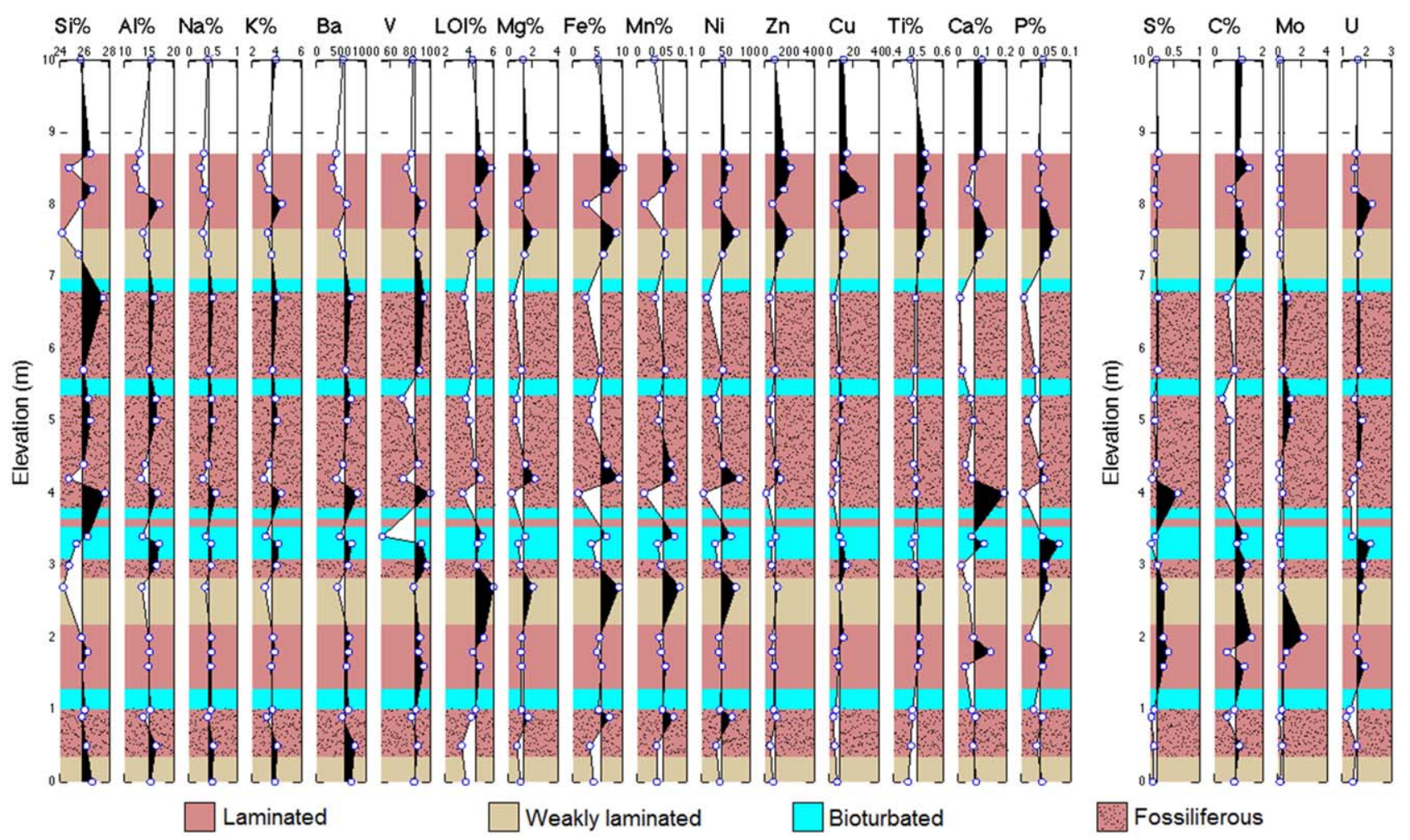

Figure 3. Stratigraphic log element abundances in ppm or in wt \% when it is underlined (\%). Field description from Ineson and Peel [2011]. (top) Buen turbidite. The vertical line locates the mean for the element. Elements dominating the "felsic" components ( $\mathrm{Al}, \mathrm{Na}, \mathrm{K}$, and $\mathrm{Ba}$ ) are more abundant at the bottom of the section.

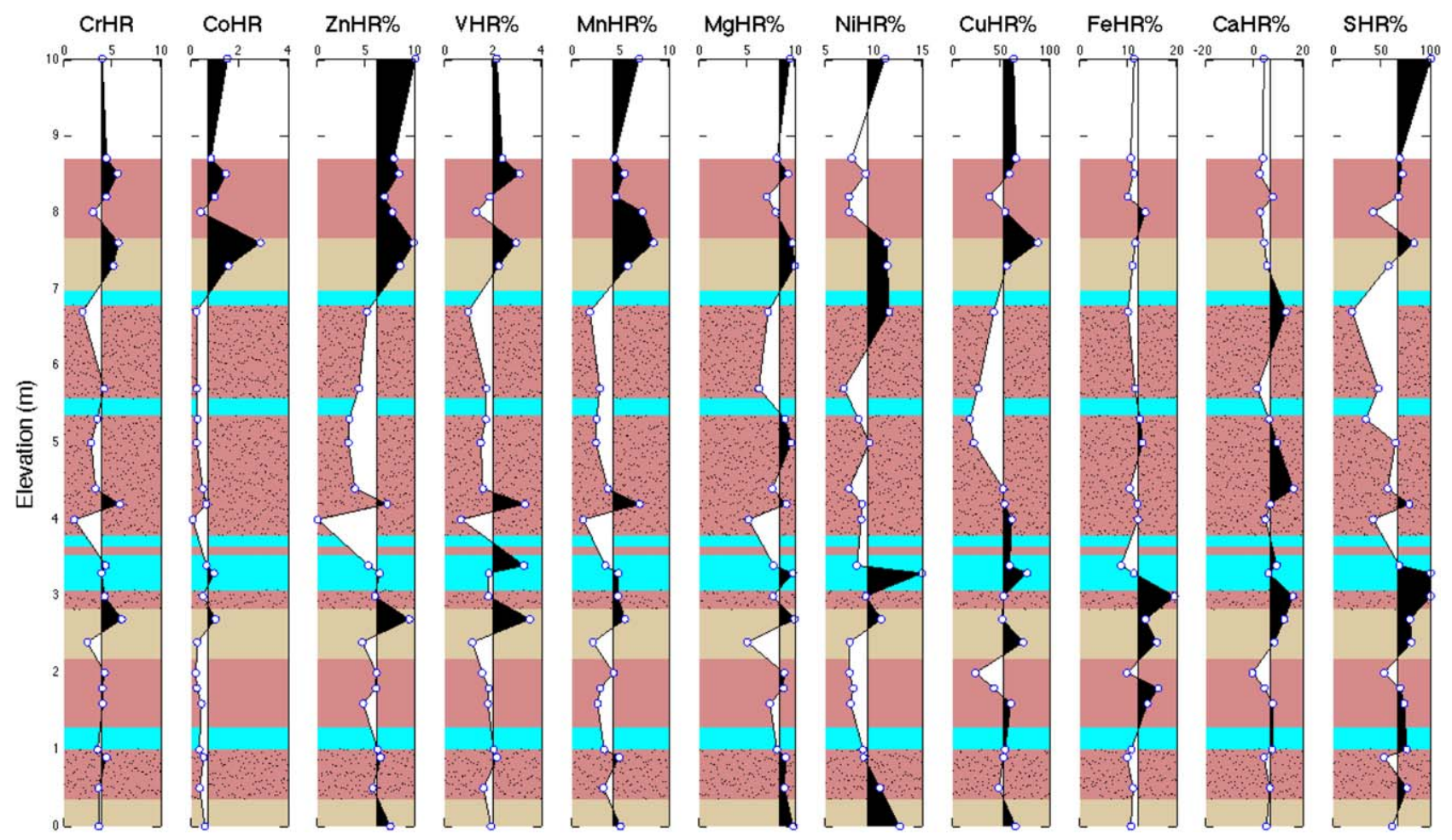

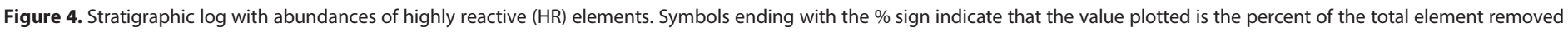
upon leaching. Note the correlation between Fe and S. See Figure 2 for color and pattern codes. 


\section{QAGU Geochemistry, Geophysics, Geosystems}
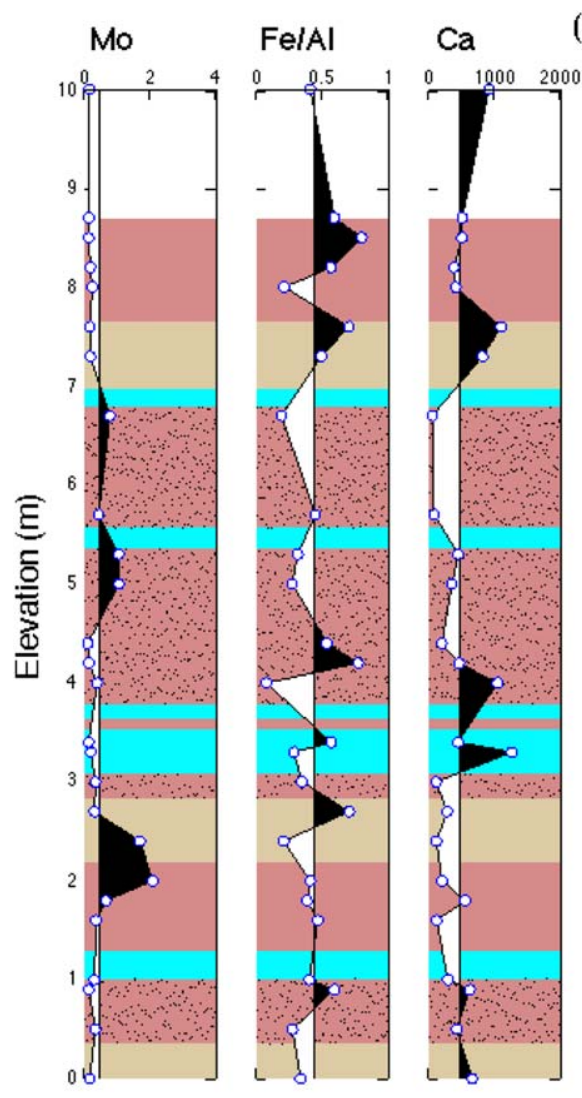

$(\mathrm{Mn} / \mathrm{Fe})_{\mathrm{HRN}}$

Alimo

$\delta^{98} \mathrm{Mo}$

DOP
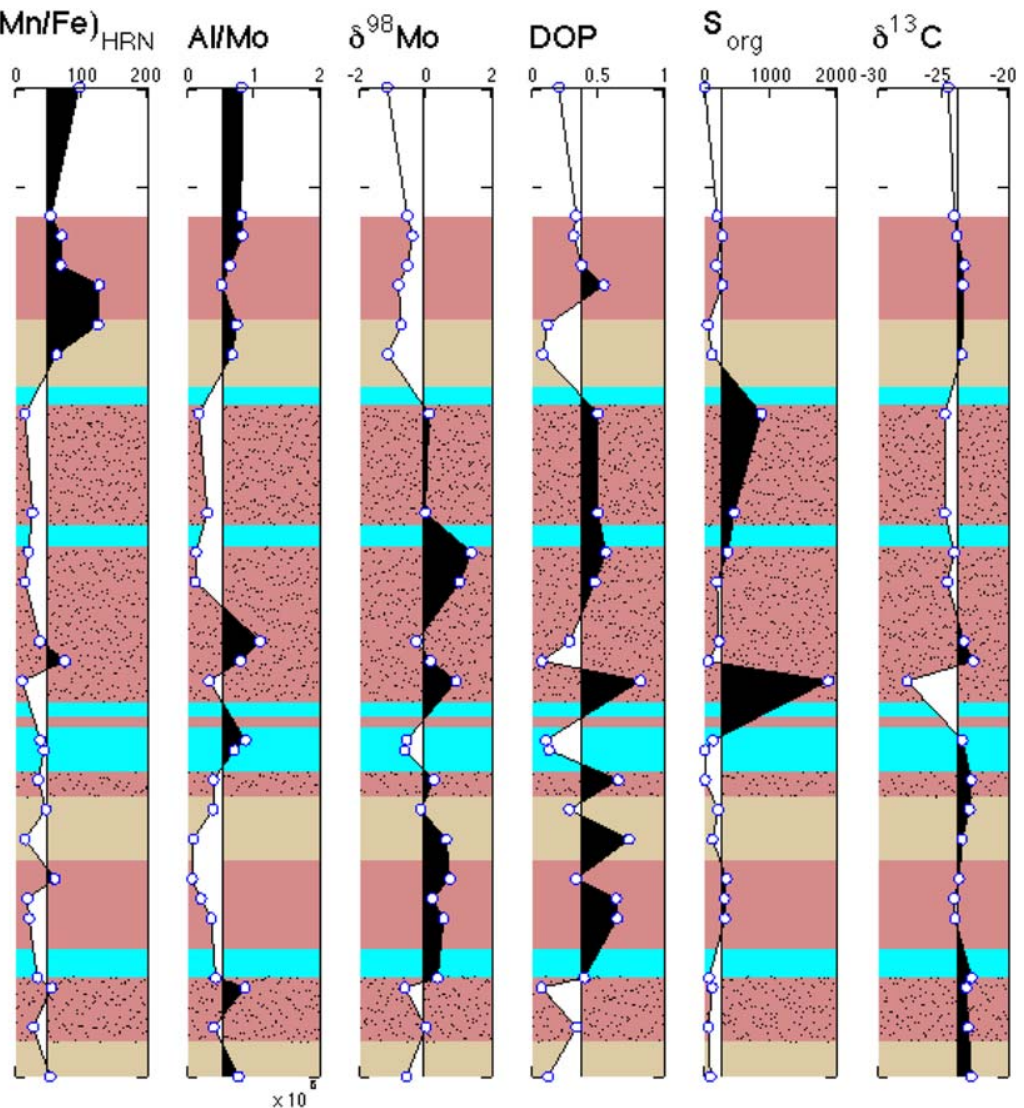

Figure 5. Diagenetic effects: stratigraphic log. Note the positive correlation between $\delta^{98}$ Mo and DOP (Degree of Pyritization) and the negative correlation between $\delta^{98}$ Mo and (Mn/ $\mathrm{Fe})_{\mathrm{HRN}}$ and $\delta^{98} \mathrm{Mo}$ and $\mathrm{Al} / \mathrm{Mo}$ (the subscript $\mathrm{N}$ indicates that the ratio was normalized to the whole-rock value).

for most elements. $\mathrm{Na}, \mathrm{K}$, and Ba tend to define alignments of lesser quality, but we will nevertheless consider these elements together with the others.

Principal component analysis shows one predominant component accounting for $55 \%$ of the variance and other minor components with a contribution of 7-11\% each. Factor analysis with three factors shows strong correlations between some elements (Table 4). A first factor opposes a mineralogical component including $\mathrm{Fe}, \mathrm{Mn}, \mathrm{Mg}, \mathrm{Ni}$, and loss on ignition (LOI), and thereafter be referred to as "mafic," to as "felsic" component, which includes $\mathrm{Al}, \mathrm{Na}, \mathrm{Ba}$, and $\mathrm{K}$. Elements positively correlate within a particular group, whereas the two groups correlate negatively. Calcium, which is particularly diluted in these samples, does not correlate with any particular element. $\mathrm{C}$ and $\mathrm{P}$ are rather poorly correlated.

Element concentrations are also shown as an overlay on the stratigraphic log (Figure 3). Some chemical wiggles are visible, in particular between $\sim 3.4$ and $7.3 \mathrm{~m}$, which is where most of fossiliferous beds occur. The felsic group of elements clearly dominates the lower section up below $\sim 3.4 \mathrm{~m}$ from the bottom. The mafic group of elements dominates the upper section from $7.3 \mathrm{~m}$ up. The intermediate part of the section, shows less variable compositions. Mo and S, two redox-sensitive elements, do not seem to correlate with any other element.

With rare exceptions, the proportion of $\mathrm{HCl}$-soluble (highly reactive or $\mathrm{HR}$ ) elements is less than $15 \%$, except for $\mathrm{Cu}$, and in particular S, for which up to $100 \%$ of the element can be leached out. The profiles show no identifiable trend or pattern that could be connected with stratigraphy. An important proxy of oxygenation is the Degree-Of-Pyritization (DOP) [Berner, 1980]. DOP is calculated from the amount of Fe held in pyrite (Py), i.e.,

$$
\mathrm{Fe}_{\mathrm{Py}}=\mathrm{Fe}_{\mathrm{HR}}-(\mathrm{Fe} / \mathrm{Mn})_{0} \times \mathrm{Mn}_{\mathrm{HR}}
$$

in which $(\mathrm{Fe} / \mathrm{Mn})_{0}$ is the ratio of the sulfide-free leachable fraction, so that 

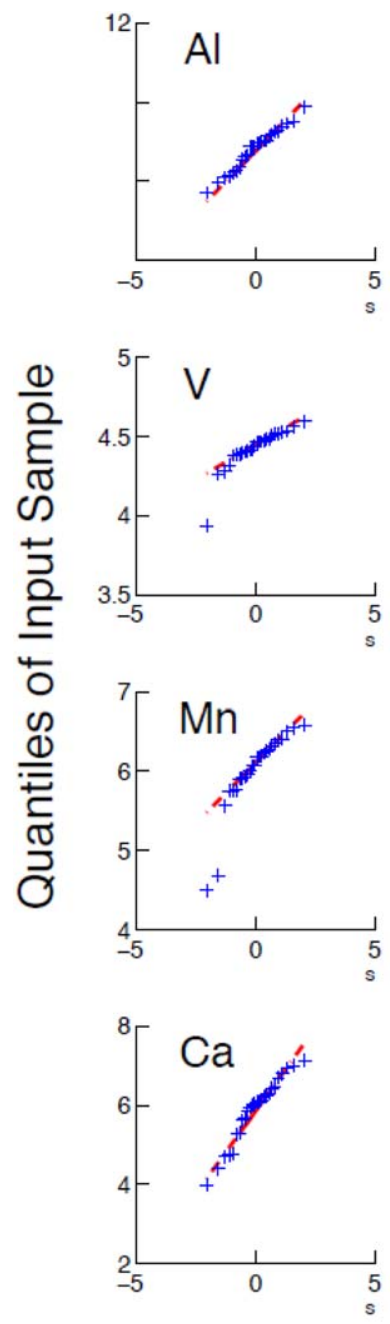
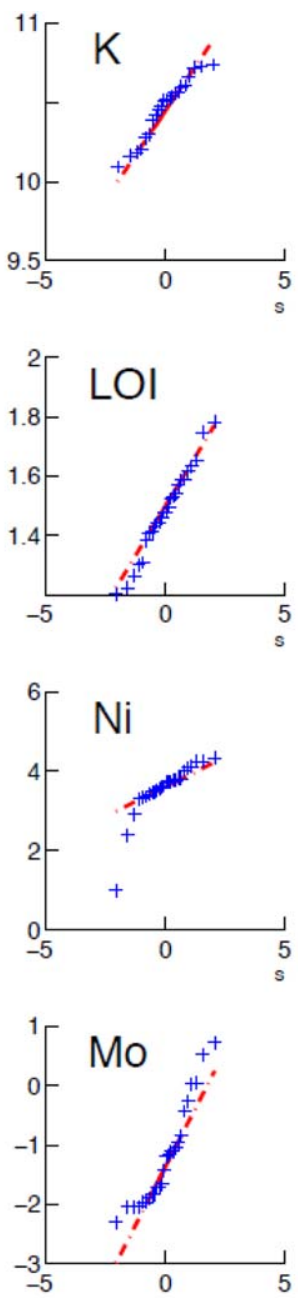

\section{Standard Normal Quantile}
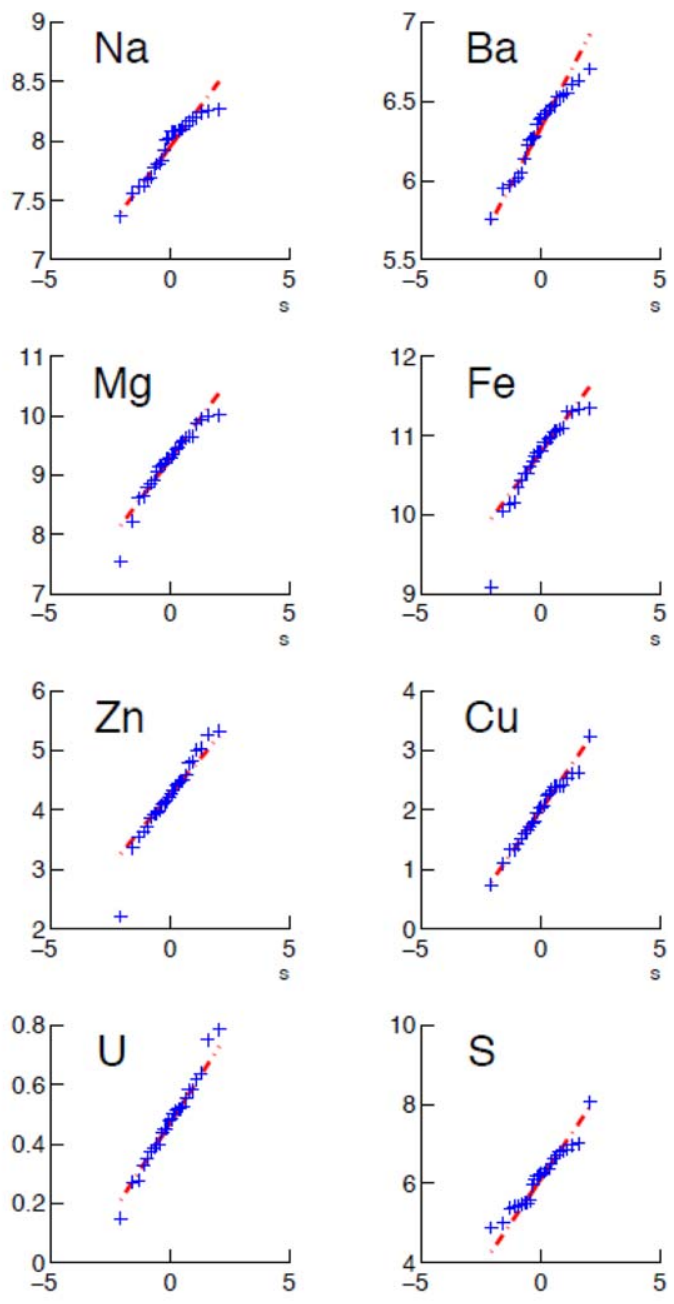

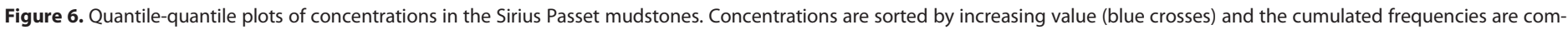

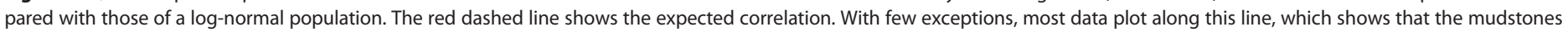
can be considered as a single population.

$$
\mathrm{DOP}=\left(\mathrm{Fe}_{\mathrm{Py}} / \mathrm{Fe}_{\mathrm{HR}}\right)=1-(\mathrm{Fe} / \mathrm{Mn})_{0} /(\mathrm{Fe} / \mathrm{Mn})_{\mathrm{HR}}
$$

On the grounds that the $(\mathrm{Mn} / \mathrm{Fe})$ is much lower in sulfides than in any other soluble mineral phase, we chose the $(\mathrm{Fe} / \mathrm{Mn})_{0}$ ratio as the lowest value ( 200) observed in the sample set. The DOP values range from $\sim 0$ to 0.7 (mean 0.36), with lower values being concentrated in bioturbated layers. A lower (Fe/ $\mathrm{Mn})_{0}$ ratio would somewhat reduce the range of DOPs but not their relative values. DOP and organic sulfur $\mathrm{S}_{\text {org }}$ calculated as the difference between total $\mathrm{S}$ and $\mathrm{S}_{\mathrm{HR}}$ are to a large extent anticorrelated. The positive correlations between $\mathrm{DOP}$ and $\mathrm{V} /(\mathrm{V}+\mathrm{Ni})$ in the reactive fraction (Figure $7 \mathrm{a}$ ) and of $\mathrm{Fe}_{\mathrm{Py}}$ with $\mathrm{S}_{\mathrm{HR}}$ (Figure $7 \mathrm{~b}$ ) indicate that the DOP and Py estimates are robust.

In addition, to DOP, other elemental ratios, notably $\mathrm{Fe}_{\text {tot }} / \mathrm{Al}_{\text {tot }}$ and $\mathrm{Fe}_{\mathrm{HR}} / \mathrm{Fe}_{\text {tot }}$ [Berner, 1980; Lyons et al., 2009; Raiswell et al., 1994], Mo/Al [Jacobs et al., 1987] and Mo abundances [Helz et al., 1996; Tribovillard et al., 2006; Xu et al., 2012] are also used as indicators of oxygenation. The values of $\mathrm{Fe}_{\mathrm{tot}} / \mathrm{Al}_{\mathrm{tot}}$, which vary from 0.07 to 0.79 , and $\mathrm{Mo} / \mathrm{Al}$ (in the $10^{-6}$ range) are not distinguishable from the range of shale compositions [McLennan et al., 1983] and are about two orders of magnitude lower than Cambrian black shales [Xu et al., 2012]. All but three $\mathrm{Fe}_{\mathrm{HR}} / \mathrm{Fe}_{\text {tot }}$ ratios fall in the range of $8.4-14.0 \%$, which indicate that only a small fraction of Fe resides in pyrite.

The fairly constant $\delta^{56} \mathrm{Fe}$ values $(0.15-0.36 \%$ ) are not very different from the igneous average and are reminiscent on observations made on both modern river suspended load [Bergquist and Boyle, 2006; Escoube et al., 2009; Fantle and DePaolo, 2004] and soils. Likewise, the range of $\delta^{66} \mathrm{Zn}(0.09-0.35 \%$ ) is consistent with 
Table 4. Three-Component Factor Decomposition of Major and Trace Elements for Sirius Passet Mudstones (Varimax Mode) $^{\mathrm{a}}$

\begin{tabular}{lrrr} 
& \multicolumn{3}{c}{ Factor Loadings } \\
\cline { 2 - 4 } & \multicolumn{1}{c}{1} & \multicolumn{1}{c}{ 2 } \\
\hline $\mathrm{SiO}_{2}$ & -0.31 & -0.18 & $-\mathbf{0 . 8 4}$ \\
$\mathrm{Al}_{2} \mathrm{O}_{3}$ & $-\mathbf{0 . 9 6}$ & -0.18 & -0.07 \\
$\mathrm{Fe}_{2} \mathrm{O}_{3} \mathrm{~T}$ & $\mathbf{0 . 8 5}$ & 0.30 & 0.39 \\
$\mathrm{MnO}$ & $\mathbf{0 . 7 1}$ & $\mathbf{0 . 5 0}$ & 0.19 \\
$\mathrm{MgO}$ & $\mathbf{0 . 8 2}$ & 0.25 & 0.47 \\
$\mathrm{CaO}$ & -0.10 & -0.35 & 0.01 \\
$\mathrm{Na}{ }_{2} \mathrm{O}$ & $-\mathbf{0 . 8 5}$ & -0.18 & -0.41 \\
$\mathrm{~K}_{2} \mathrm{O}$ & $-\mathbf{0 . 9 2}$ & -0.35 & -0.13 \\
$\mathrm{TiO}_{2}$ & $\mathbf{0 . 6 5}$ & $-\mathbf{0 . 6 4}$ & 0.32 \\
$\mathrm{P}_{2} \mathrm{O}_{5}$ & 0.11 & 0.21 & $\mathbf{0 . 7 9}$ \\
$\mathrm{S}$ & -0.08 & $-\mathbf{0 . 6 1}$ & -0.24 \\
$\mathrm{C}$ & 0.22 & -0.13 & 0.51 \\
$\mathrm{Ba}$ & $-\mathbf{0 . 8 8}$ & -0.18 & -0.34 \\
$\mathrm{~V}$ & -0.47 & -0.47 & 0.03 \\
$\mathrm{LOI}$ & $\mathbf{0 . 6 8}$ & -0.04 & 0.53 \\
$\mathrm{Ni}$ & $\mathbf{0 . 7 0}$ & 0.45 & 0.45 \\
$\mathrm{Zn}$ & $\mathbf{0 . 8 2}$ & 0.03 & 0.40 \\
$\mathrm{Cu}$ & 0.33 & -0.09 & 0.25 \\
$\mathrm{Mo}$ & -0.20 & -0.25 & -0.27 \\
\hline
\end{tabular}

${ }^{a}$ The first factor shows the prevalence of a rather dry "felsic" component (negative loadings) dominated of a wet "mafic" component (positive loadings) dominated by Fe, Mg, Ni, Mn, and LOI, most likely chlorite \pm smectite. Although the abundance of $\mathrm{Ca}$ is particularly low, this element is decorrelated from any other elements. Most significant values in bold. by $\mathrm{Al}, \mathrm{K}, \mathrm{Na}$, and $\mathrm{Ba}$, most likely illite $\pm \mathrm{K}$-feldspar, and

a dominantly detrital origin [Pons et al., 2011]. Although uncorrelated, the variations of $\delta^{65} \mathrm{Cu}(-0.63$ to $+0.54 \%)$ and $\delta^{34} \mathrm{~S}$ (9.9 to $23.1 \%$ ) may betray some diagenetic fractionation in a sulfide-rich environment [Fujii et al., 2013].

$\delta^{98} \mathrm{Mo}$ correlates negatively with $(\mathrm{Mn} / \mathrm{Fe})_{\mathrm{HR}} /(\mathrm{Mn} / \mathrm{Fe})_{\text {tot }}$ (Figure $7 \mathrm{c}), \mathrm{Zn}_{\mathrm{HR}} / \mathrm{Zn}_{\text {tot }}$, and $\mathrm{Mn}_{\mathrm{HR}} / \mathrm{Mn}_{\text {tot }}$, and negatively with DOP. It correlates with $\mathrm{Me} / \mathrm{Mo}$, where $\mathrm{Me}=\mathrm{Al}, \mathrm{K}, \mathrm{Na}, \mathrm{Ba}$, and $\mathrm{V}$ (Figure $7 \mathrm{~d}$ ). $\delta^{13} \mathrm{C}$ correlates negatively with $\mathrm{S}_{\text {org }}$ while $\delta^{66} \mathrm{Zn}$ correlates with $\mathrm{Mn} / \mathrm{Fe}$. Isotopic profiles in general (Figure 8 ) are rather loosely correlated, with the possible exception of $\delta^{98} \mathrm{Mo}$ and $\delta^{65} \mathrm{Cu}$, and to a lesser extent $\delta^{13} \mathrm{C}$ and $\delta^{66} \mathrm{Zn}$. With exception of sample R17, $\delta^{13} \mathrm{C}(-25.0$ to $-22.8 \%$ ) also vary in a small interval.

\subsection{U-Th-Pb ages}

Several major groups of concordant or nearly concordant ages are identified (supporting information Table 1 and Figure 9):

1. Zircons concordant at $\sim 640 \mathrm{Ma}$ reflect an input from magmatic rocks associated with the East African phase of the Pan-African orogeny [lizuka et al., 2013; Meert, 2003].

2. Older concordant zircons reflecting ages between 1250 and $\sim 2400$ Ma with peaks at $\sim 1900 \mathrm{Ma}$ and $\sim 2400 \mathrm{Ma}$ which are well identified in Northern Greenland gneisses and metasediments [Nutman et al., 2008].

The most remarkable result is therefore the coexistence in the same sample of old Proterozoic zircons, not unexpected from the local geology, with exotic 640 Ma old zircons.

\section{Discussion}

The restriction of so many Lagerstätte to short time intervals, a few Ma or even less if they consist of multiple pulses [Maloof et al., 2010; Zhu et al., 2006], suggests that they were associated to a transient yet widespread oceanic or atmospheric environment. The Cambrian $\delta^{13} \mathrm{C}$ record indeed attests to rather fast fluctuations in the fractional burial and erosion of organic carbon [Derry et al., 1994; Maloof et al., 2010, and references therein] on Ma time scales. The presence of elevated mountain ranges and strong erosion rates seem supported by the generally high ${ }^{87} \mathrm{Sr} /{ }^{86} \mathrm{Sr}$ ratios in Cambrian carbonates in the wake of the Pan-African collision [Derry et al., 1994; Maloof et al., 2010, and references therein]. Before addressing how the Sirius Passet Lagerstätte compares with similar deposits of the same age, its depositional environment should be decrypted. It will be first shown that sediments can be broken down into two major components. Then the issues of diagenetic transformations and of the deposition environment will be discussed.

\subsection{Lithological Components}

The major element analyses show that the Sirius Passet mudstones formed by erosion of altered basalts on the one hand and of K-rich granites on the other hand. High $(\mathrm{Al} / \mathrm{Mg})$ and $(\mathrm{Ba} / \mathrm{Ca})$ ratios, and the low $(\mathrm{Ca} / \mathrm{Mg})$ ratios of the samples differ from those of typical post-Archean shales and pelagic sediments [McLennan et al., 1983; Plank and Langmuir, 1998; Taylor and McLennan, 1985]. Submillimeter-sized agglomerates of quartz and sericitized K-feldspar are actually observable in thin sections (Figure 10). Nesbitt and Young's [1989] projection (Figure 11) shows that such lithologies are dominated by water-poor alteration products of K-feldspar (illite or muscovite) and by hydrous mafic clays. The correlation of the loss-on-ignition with $\mathrm{Mg}, \mathrm{Fe}, \mathrm{Mn}, \mathrm{Ni}$, and $\mathrm{Zn}$ and the low $\mathrm{Ca}$ of the samples are strong indications that the protolith of the mafic mineralogical component was dominated by smectite or chlorite. In contrast, high 

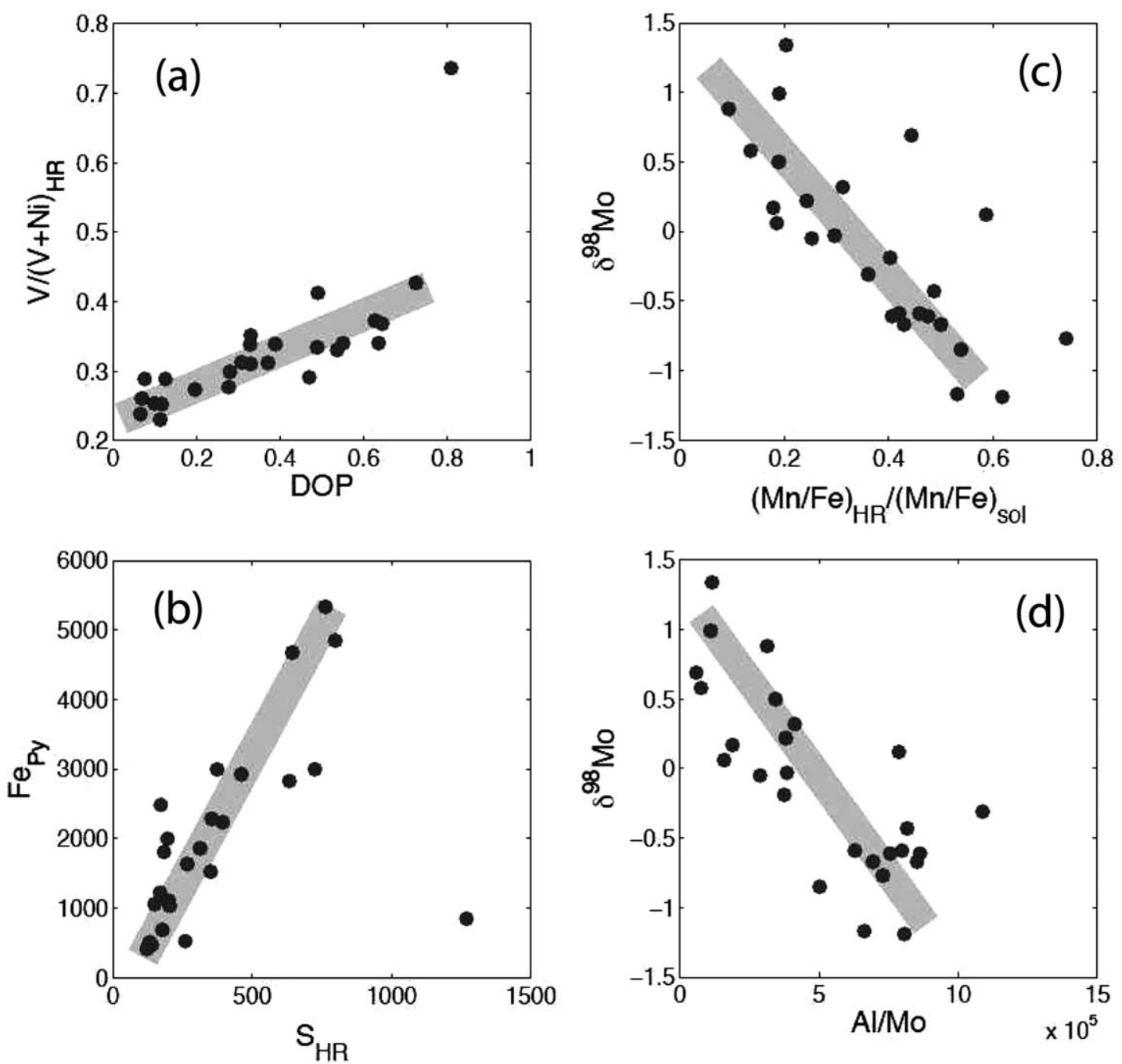

Figure 7. Diagenetic effects: some correlations. (a) The correlation between the Degree-Of-Pyritization DOP and the $\mathrm{V} /(\mathrm{V}+\mathrm{Ni}), \mathrm{V}$ being a redox-sensitive element demonstrates that DOP is a reliable indicator of redox conditions in the sediment. (b) This figure emphasizes the correlation between "pyrite iron" as calculated in the Results section and reactive sulfur. (d) The negative correlations between $\delta^{98}$ Mo and $\mathrm{Mn}_{\mathrm{HR}} / \mathrm{Mn}_{\text {tot }}$ and $(\mathrm{Mn} / \mathrm{Fe})_{\mathrm{HR}} /(\mathrm{Mn} / \mathrm{Fe})_{\text {tot }}$ (c) and $\mathrm{Al} / \mathrm{Mo}$ (d) reflect the mixing between an Al-free Mo end-member with $\delta^{98} \mathrm{Mo} \sim 1.3 \%$ and an Al-rich end-member with $\delta^{98} \mathrm{Mo} \sim<-1.5 \%$, which we interpret as Mo adsorbed on FeMn-oxides particulates settling in the water column. The intercept at $\mathrm{Al} / \mathrm{Mo}=0$ is $\delta^{98} \mathrm{Mo} \sim 1.3 \%$ and is consistent with the value of Cambrian seawater [Lehmann et al., 2007]. The Al-rich endmember with $\delta^{98} \mathrm{Mo} \sim<-1.5 \%$ is interpreted as Mo adsorbed on FeMn-oxides particulates settling in the water column. These correlations reflect the progressive release of isotopically light Mo adsorbed on oxihydroxides dispersed in the mud.

$\mathrm{K} / \mathrm{Na}$ ratios of 12 and the overall low concentrations of Ca suggest that K-feldspar and quartz, both minerals being particularly resistant to weathering, account for most of the felsic mineralogical component. The high chemical index of alteration, $\mathrm{CIA}=100 \times \mathrm{Al}_{2} \mathrm{O}_{3} /\left(\mathrm{Al}_{2} \mathrm{O}_{3}+\mathrm{CaO}+\mathrm{Na}_{2} \mathrm{O}+\mathrm{K}_{2} \mathrm{O}\right)$ [Nesbitt and Young, 1982], (82 \pm 2$)$ of these sediments suggests that the protolith may have formed at low latitudes, possibly under tropical conditions.

The major fossiliferous units $C$ and $D$ appear after a significant change from layers rich in the felsic component to layers rich in mafic muds. Smectite is known to increase porosity and its abundance correlates well with organic carbon [Bennett et al., 1999]. Smectite would in contrast reduce permeability and therefore inhibit percolation of diagenetic fluids.

Calcium concentrations are remarkably low and their concentrations in Sirius Passet sediments vary independently of any other concentrations or isotope compositions. Such low Ca contents may reflect that calcium carbonates and phosphates were dissolved during diagenesis, while $\mathrm{K}$ and $\mathrm{Na}$ were left untouched in phyllosilicates 


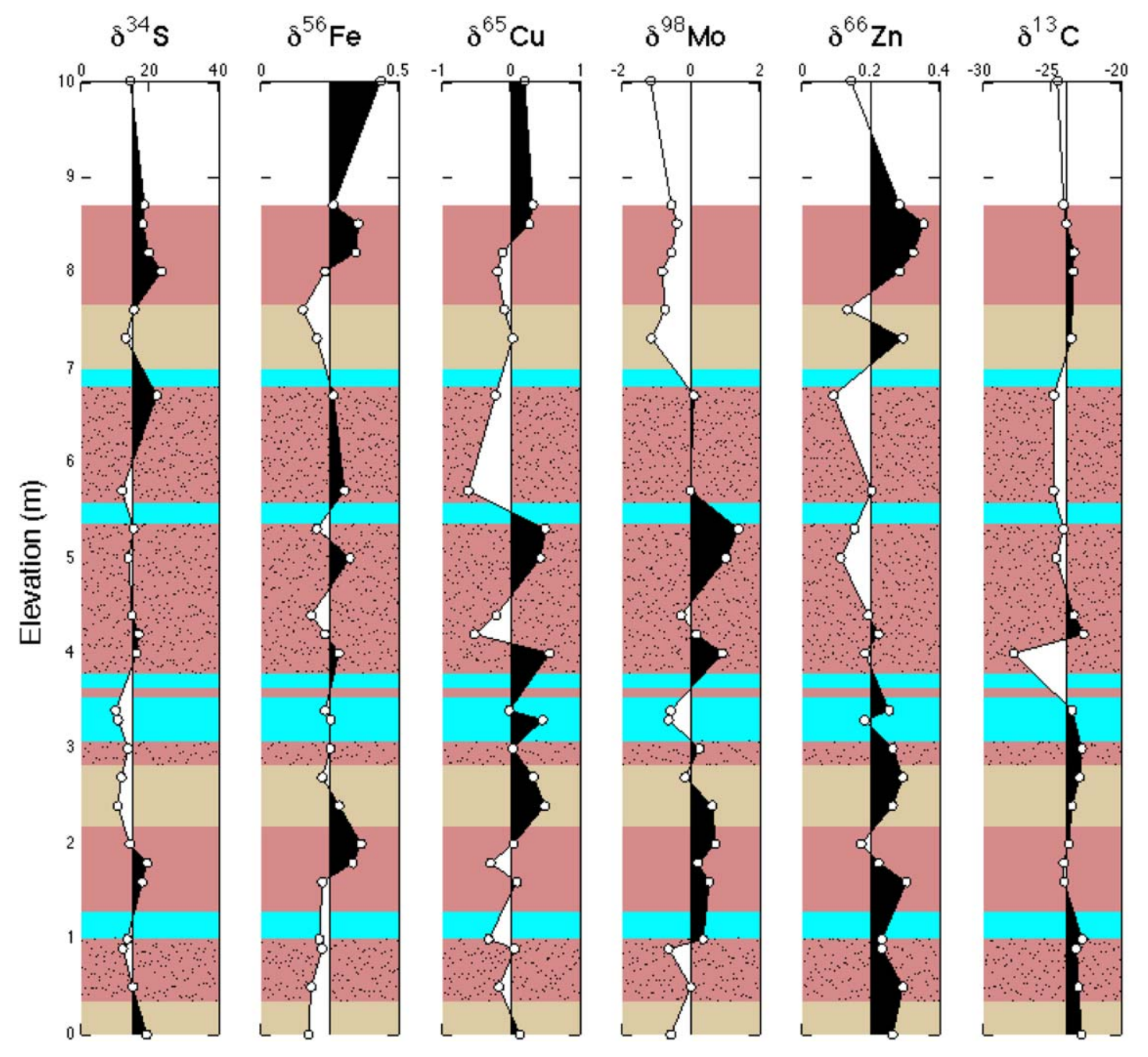

Figure 8. Stratigraphic log with the isotopic abundances of $\mathrm{S}, \mathrm{Fe}, \mathrm{Cu}, \mathrm{Mo}, \mathrm{Zn}$, and $\mathrm{C}$. See Figure 1 for color and pattern codes.

and feldspars. Calcium can first be present in the form of phosphatized gastric diverticulæ of large arthropods, notably Buenellus higginsi and Siriocaris trollae [Lagebro et al., 2009], a feature shared with the Burgess and Maotianshan shales [Briggs, 1981; Butterfield, 2002]. Although 0.1\% apatite would account for all the Ca present in the rock, less than $15 \% \mathrm{Ca}$ is reactive, so that apatite cannot represent a substantial fraction of Ca in the sample. The calcium of nonfossiliferous layers must therefore be hosted in a specific, acid-resistant carrier unrelated to either mafic or felsic components, possibly an authigenic zeolite or some organic derived material.

The provenance of each component still remains enigmatic. The well-rounded shape of most zircon crystals (Figure 2) attests to attrition during transportation. The old ages (1250-2400 Ma) (Figure 9) are consistent with Nutman et al.'s [2008] results on zircons extracted from granites, gneisses, and metasediments in Northwestern Greenland. In contrast, the presence of concordant Pan-African zircon ages (610-660 Ma) attest to long-distance transport: such ages are essentially absent on the Laurentia continent [Rino et al., 2008; Whitmeyer and Karlstrom, 2007] and the main potential sources of Gondwana felsic rocks lie beyond the lapetus ocean [Hoffman, 1991; lizuka et al., 2013; Kusky et al., 2003; Meert, 2003]. Beyond the point of a remote contribution, it is difficult to assess a particular provenance to the individual components.

\subsection{Diagenesis}

Overall, the diagenetic transformations are fairly standard [e.g., Berner, 1980]. Sulfur and copper isotope variations stand for primary evidence of diagenesis in a sulfate-bearing environment, but the lack of correlation 


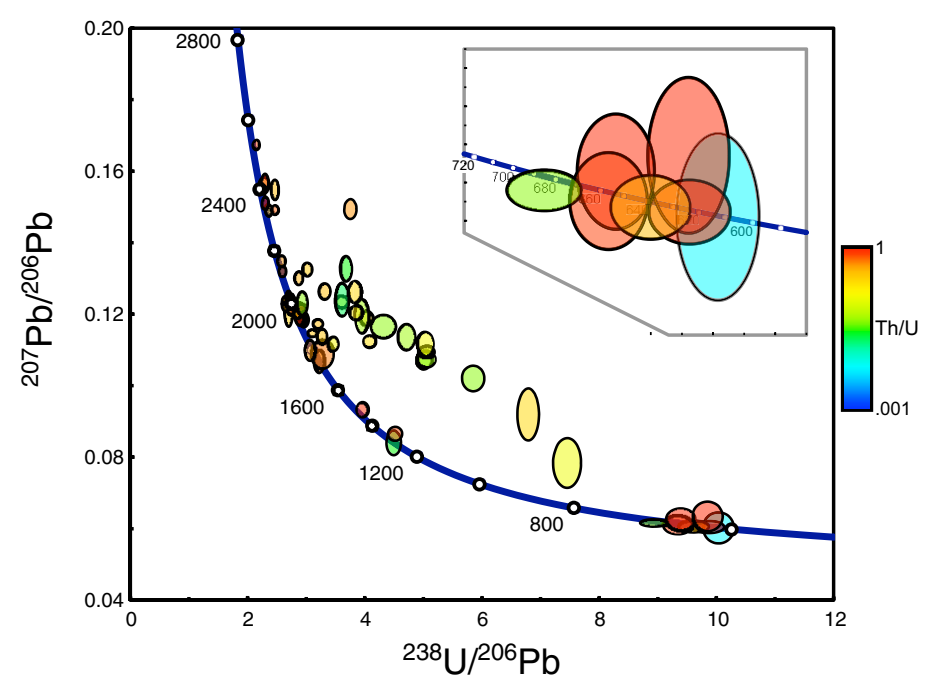

Figure 9. U-Pb results on 58 zircon crystals (supporting information Table 1) separated from a sample of the Buen formation collected a few meters away from the fossiliferous layers. The older concordant ages peak at $\sim 1900$ and $\sim 2400 \mathrm{Ma}$, which correspond to well-identified tectonic ages in Northern Greenland gneisses and metasediments [Nutman et al., 2008]. Younger concordant ages at $\sim 640$ Ma reflect an input from magmatic rocks associated with the East African phase of the Pan-African orogeny [lizuka et al., 2013; Meert, 2003]

therefore assume that the negative $\delta^{98}$ Mo values of the Lagerstätte are characteristic of Mo adsorption of FeMn oxides under oxic or suboxic conditions such as those prevailing in modern seawater [Barling et al., 2001; Goldberg et al., 2009; Siebert et al., 2001, 2003]. In contrast, positive $\delta^{98}$ Mo values reveal the diagenetic sulfidization of marine molybdate to oxythiomolybdates and thiomolybdate and the subsequent adsorption of Mo on sulfides [Bostick et al., 2002] and other particles. This simple interpretation is supported by the positive correlation between $\delta^{98} \mathrm{Mo}$ and $\mathrm{Me} / \mathrm{Mo}$, where Me stands for $\mathrm{Al}, \mathrm{K}, \mathrm{Na}$, Ba, and $\mathrm{V}$ (Figure 7a). The intercept at $\mathrm{Al} / \mathrm{Mo}=0$ is $\delta^{98} \mathrm{Mo} \sim 1.3 \%$ and is consistent with the value of Cambrian seawater [Lehmann et al., 2007]. This correlation may be interpreted as a mixing line between an Al-free Mo end-member with $\delta^{98}$ Mo $\sim 1.3 \%$ and an Al-rich end-member with $\delta^{98} \mathrm{Mo} \sim<-1.5 \%$, which we interpret as Mo adsorbed on FeMnoxides particulates settling in the water column.

Reduction of solid Mn dioxide and dissolution of $\mathrm{Mn}$ as $\mathrm{Mn}^{2+}$ during early diagenesis precedes the reductive dissolution of Fe oxihydroxides [Berner, 1980; Froelich et al., 1979]. The negative correlation of $\delta^{98} \mathrm{Mo}$ with $\mathrm{Mn}_{\mathrm{HR}} / \mathrm{Mn}_{\text {tot }}$ and $(\mathrm{Mn} / \mathrm{Fe})_{\mathrm{HR}} /(\mathrm{Mn} / \mathrm{Fe})_{\text {tot }}$ (Figure $\left.7 \mathrm{c}\right)$ therefore reflects the progressive release of isotopically light Mo adsorbed on oxihydroxides dispersed in the mud. This observation is consistent with the positive correlation of $\delta^{98}$ Mo with DOP, which indicates that oxide dissolution is accompanied by pyrite formation. The negative correlation of $\delta^{13} \mathrm{C}$ with $\mathrm{S}_{\text {org }}$ (not shown) attests to the dissimilatory reduction of sulfate, which is used by metabolic processes as electron acceptor: sulfate from interstitial fluids is converted to pyrite, while isotopically heavy $\mathrm{CO}_{2}$ is lost from the organic fraction. The lack of a correlation between $\delta^{13} \mathrm{C}$ and $\delta^{34} \mathrm{~S}$ suggests that this process operated to some extent under open system conditions. The decrease of $\mathrm{Zn}_{\mathrm{HR}} / \mathrm{Zn}_{\text {tot }}$ with increasing $\delta^{98}$ Mo indicates that $\mathrm{Zn}$ is also released during the remobilization of $\mathrm{Mn}$-rich oxihydroxides, which is consistent with the well-documented association of $\mathrm{Zn}$ and $\mathrm{Mn}$ in modern deep-sea nodules [Calvert and Price, 1977; Piper, 1988].

Reductive diagenesis has consequences on other isotopic systems. The negative correlation between $\delta^{13} \mathrm{C}$ and $\mathrm{S}_{\text {org }}$ is inconsistent with a control by marine productivity. We therefore assume that variations of $\mathrm{S}_{\text {org }}$ reflect oxidation of organic material in the sediment. A possibility is that, $\delta^{13} \mathrm{C}$ increases from the minimum values upon loss of isotopically light methane and $\mathrm{H}_{2} \mathrm{~S}$ from the organic material in sulfate-free environments, and more generally, upon thermal evolution of the kerogen [Barnes and Goldberg, 1976; Reeburgh and Heggie, 1974]. Alternatively, some enzymatic pathways based on acetyl-CoA are known to increase the $\delta^{13} \mathrm{C}$ of the organic residues [Londry and Des Marais, 2003]. 

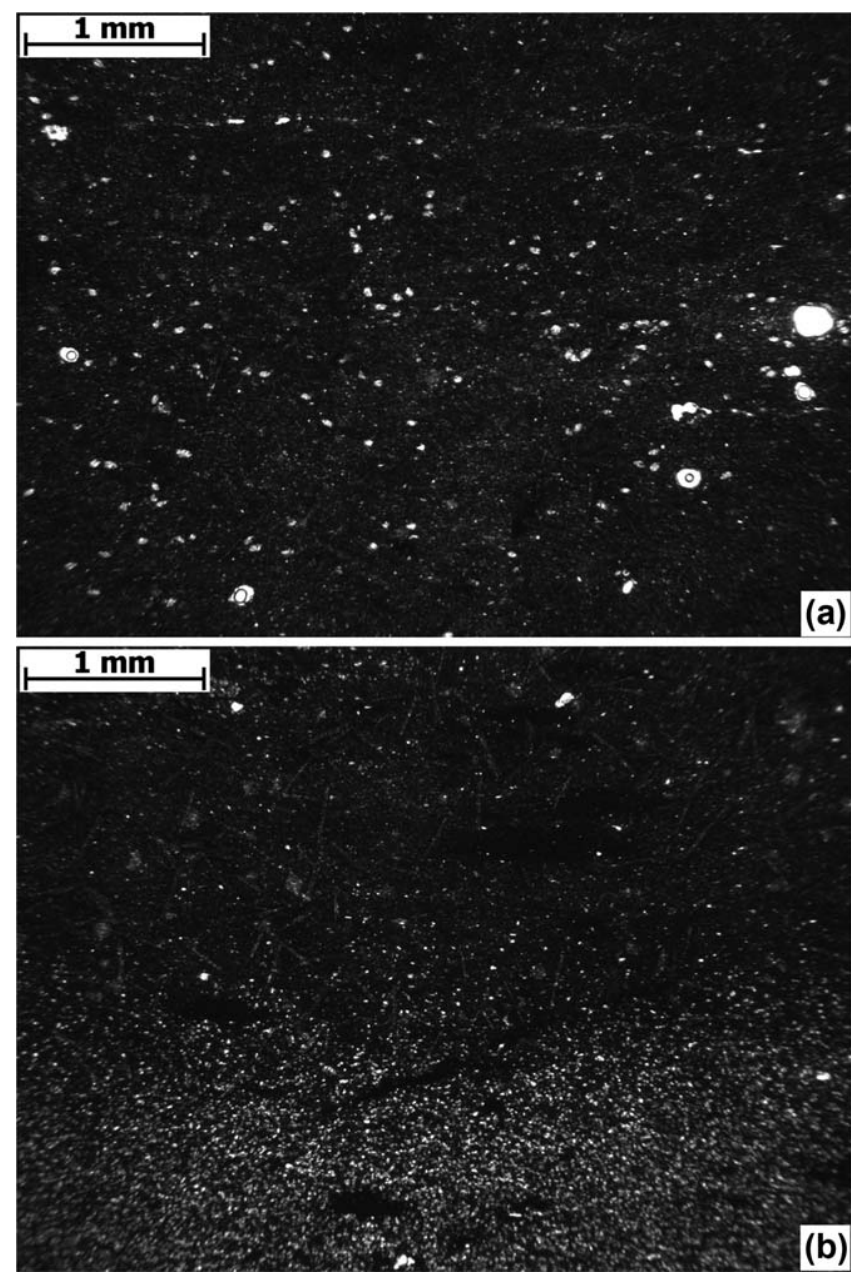

Figure 10. Thin-section photomicrographs from samples (a) 2.4 and (b) 2. Photomicrograph (a) shows scattered submillimeter agglomerates of quartz, feldspar, and/or sericite (in white) embedded in a fine clay matrix, probably composed of quartz, chlorite, illite/ smectite and organic matter. There is no grain-size grading visible here. Photomicrograph (b) shows two distinct distributions: (i) the same matrix described in the precedent photomicrograph with chloritized sponge spicules visible throughout the upper part, and (ii) a siltier component, mainly quartz grains with chlorite inclusions, in the lower part. We believe that this last component coincided with high-energy events, typically storms.
Second, the overall correlation of $\delta^{66} \mathrm{Zn}$ with $\mathrm{Mn} / \mathrm{Zn}$ indicates the mixing of isotopically undifferentiated $\mathrm{Zn}$ (low Mn/Zn, $\delta^{66} \mathrm{Zn}$ $\sim 0.3$ ) ubiquitous in igneous rocks and shales [Albarède, 2004] with a high $\mathrm{Mn} / \mathrm{Zn}$ component with low $\delta^{66} \mathrm{Zn}(\sim 0)$. The range of $\delta^{66} \mathrm{Zn}$ is rather narrow $(0.09$ $0.35 \%$ ) but is still significant with respect to error bars ( $\pm 0.05 \%$ ). As $\mathrm{Zn}$ concentrations vary up the section twice as much as $\mathrm{Mn}$, the second component should represent $a$ residue left by the preferential loss of a Zn-rich, isotopically heavy dissolved compound, most likely $\mathrm{Zn}$ phosphate or carbonate ions. $\mathrm{Zn}$ isotope fractionation is stronger for both phosphate and carbonate [Fujii and Albarède, 2012] while carbonates are essentially absent from the samples. As there is ample evidence for partial dissolution of phosphatized gastric diverticulæ of Siriocaris trollae and of the common trilobite Buenellus higginsi (see photos in Babcock and Peel [2007], Lagebro et al. [2009]), we conclude that the correlation between $\delta^{66} \mathrm{Zn}$ and $\mathrm{Mn} / \mathrm{Zn}$ records the loss of phosphate into diagenetic fluids. Although the lack of interstitial carbonate may also reflect inhibition of carbonate precipitation by phosphate [Burton and Walter, 1990] or anaerobic metabolism [Rhoads and Morse, 1971], we take evidence of incipient phosphate dissolution as an indication that the $\mathrm{pH}$ of interstitial fluids was decreased by $\mathrm{CO}_{2}$ resulting from the oxidation of organic material.

\subsection{Oxygenation of the Water Column}

The $\delta^{98} \mathrm{Mo}, \mathrm{Fe} / \mathrm{Mn}$, and $\mathrm{S}$ records therefore provide indications that, while pyrite is undoubtedly present, the mudstone protolith also contained iron oxihydroxides. This first conclusion is leaving us with the dilemma of an oxygen-starved sequence of muddy sediments underlying a ventilated water column. As Ineson and Peel [2011] argued that the preservation of densely distributed soft-bodied fossils suggests limited transport, we view this picture as also applicable to the environment in which the faunas lived.

There is no agreement in the literature about the ventilation status of the depositional environment of Lagerstätten. Some transition elements ratios are commonly used as geochemical proxies of the redox conditions in the overlying seawater column, but Jones and Manning [1994] pointed out that only a few of them (DOP, U/Th, Ni/Co, and V/Cr) are statistically reliable. The presence of a large fraction of smectite or chlorite could further complicate the use of these proxies. Nevertheless, using such ratios [Powell et al., 


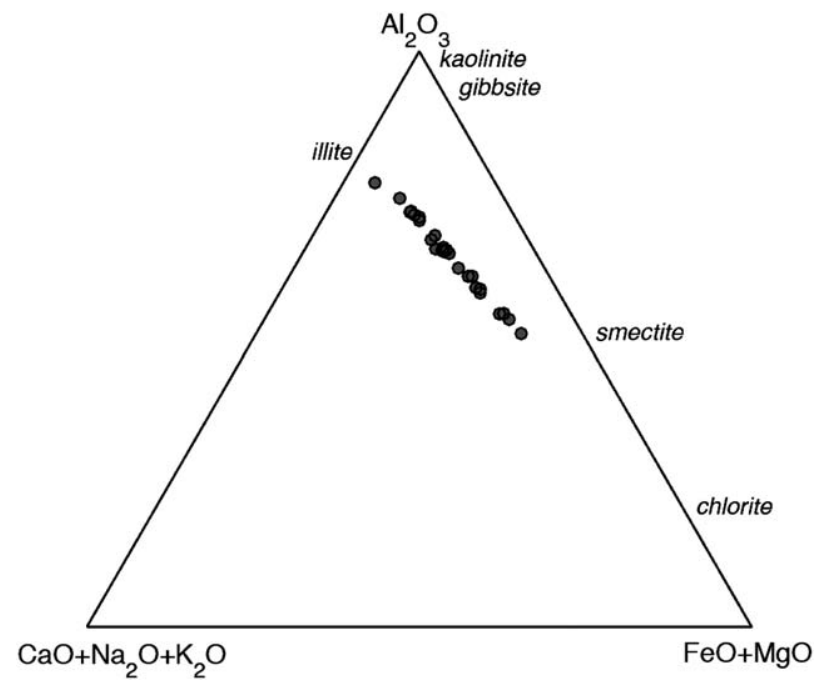

Figure 11. Plot of Sirius Passet mudstone compositions in the weathering A-CNK-FM triangle of Nesbitt and Young [1989]. The Lagerstätte samples appear to be composed of a mixture of a component dominated by illite $\pm \mathrm{K}$-feldspar and a component made of chlorite \pm smectite. Kaolinite, which attests to intense weathering, is absent. Quartz proportions may vary arbitrarily. Such compositions may be representative of tropical conditions.
2003] argued that oxygenated conditions prevailed in the water column above the Burgess Shale. McKirdy et al. [2011] arrived at a similar conclusion at Emu Bay. In contrast, Graines and Droser [2010] expressed reservations about the behavior of metal proxies under metamorphic conditions and contended that BST faunas were preserved under anoxic benthic conditions, requiring that the fossils were transported from habitable benthic environments to a preservational trap. A low level of dissolved oxygen is indeed supported by the lack of calcified organisms and, at least for the bioturbated layers, by the presence of burrows [Rhoads and Morse, 1971].

Euxinia causes Fe removal in deep water. This iron flux can be distinguished from clastic Fe flux to continental shelf by using $\mathrm{Al}$ concentrations. $\mathrm{Fe}_{\mathrm{tot}} / \mathrm{Al}_{\text {tot }}$ ratio is the prime indicator of lithogenic fluxes. Using classic sites where anoxic (Cariaco trench, Saanich Inlet) and euxinic (Black Sea) conditions are recorded in sediments, Lyons and Severmann [2006] derived a number of criteria that, at least for Sirius Passet, do not ambiguously point toward anoxia or euxinia. Although strong variations among DOP values suggest alternating periods of oxygenation and euxinia near the water-sediment interface, the $\mathrm{Fe}_{\text {tot }} / \mathrm{Al}_{\text {tot }}$ and $\mathrm{Mo}_{\text {tot }} / \mathrm{Al}_{\text {tot }}$ of the present samples do not show values that require extensive anoxic or euxinic conditions in the water column overlying the fossiliferous beds [Lyons and Severmann, 2006; Tribovillard et al., 2006; Xu et al., 2012]. It is not clear that the isotopically heavy Mo found in some of our samples signals reduced metal precipitated in the water column rather than bulk reduction of marine Mo from seawater percolating in the sediment. Seawater, at least for the modern ocean, is relatively rich in Mo, whereas the average Mo concentration in the Sirius Passet samples ( 0.4 ppm on average) is fairly low. This value is much lower than the 25 ppm cutoff identified by Scott and Lyons [2012] between noneuxinic and euxinic environments.

\subsection{Sirius Passet in the Context of Contemporaneous Cambrian Lagerstätten}

The concept of fluctuating oxycline has pervaded the literature on Lagerstätten for nearly two decades [Allison and Brett, 1995]. An oxycline is a part of the water column over which dissolved oxygen varies rapidly with depth. It is related to the concept of oxygen minimum zone (OMZ) and occurs below areas of high productivity, notably oceanic upwellings, such as coastal Peru, Namibia, and Arabia. Where the OMZ intersects the shelf definitely has an impact on benthic faunas [Levin, 2003] and locating Sirius Passet underneath an upwelling would certainly account for a thriving benthic fauna. Currently, over 1 million $\mathrm{km}^{2}$ of the modern shelf and bathyal seafloor is located within the OMZ and is permanently hypoxic [Helly and Levin, 2004]. Climate changes are known to affect the global distribution of the $\mathrm{OMZ}$ in the water column and eventually exert some stress on ecosystems, even over a decadal time scale [Stramma et al., 2008, 2010]. The fluctuating oxycline model therefore has a strong potential to explain Lagerstätten. However, mustering geochemical evidence that unambiguously supports high productivity in such an environment is a difficult task. As pointed out above, the negative correlation between $\delta^{13} \mathrm{C}$ and $\mathrm{S}_{\text {org }}$ argues against an effect of productivity on organic carbon, but diagenesis may have erased any relevant signal. The small concentrations of $\mathrm{P}$ and $\mathrm{Ca}$ are not consistent with the high phosphate contents expected from sediments underneath an upwelling. Probably the weakest point of this model is that fluctuations in the oxycline do not fit the rarity of Lagerstätten in the geological 
record: fast and large-scale changes in the Apparent Oxygen Utilization (AOU) and the OMZ are ubiquitous in the modern ocean, both in space and time [Stramma et al., 2008, 2010], and presumably so were they in the past.

If a fluctuating oxycline does not account for the bulk of sedimentology and geochemistry at Sirius Passet, some other processes must therefore be considered. McKirdy et al. [2011] argued that microbial mats might have helped promote fossil preservation by imposing a sharp redox gradient at the sediment water interface. The sedimentology at Sirius Passet Lagerstätte is still to be described in detail. Preliminary observations, however, stress the small size (20-50 $\mu \mathrm{m})$ of quartz grain, the apparent lack of graded bedding, the presence of a large clay fraction, and the occasional presence of large grains in the Sirius Passet Lagerstätte, conjure up a very different depositional setting similar to that of wind-blown (eolian) deepsea sediments [Rea, 1994]. The large grains are taken as an indicator of storms [Rea, 1994] or of the particularly strong winds of the winter monsoon [Xiao et al., 1995]. As discussed above, the high ${ }^{87} \mathrm{Sr} /{ }^{86} \mathrm{Sr}$ of carbonates indicates that the Cambrian was a time of intense erosion, and therefore of very high relief similar to the modern Himalayas. The preferential collection of continents in the Southern hemisphere [Hoffman, 1991; Li et al., 2008; McCausland et al., 2007] and the presence the young Pan-African mountain ranges may have favored fluctuations of the meteorological equator with climatic zones controlled by a dry monsoon regime similar to that prevalent in modern Asia east of the Himalayas. Convergence of Cambrian continents in the Southern Hemisphere toward low latitudes may have promoted hot and dry climates and desertification at low elevation. Modern low-latitude deserts are a powerful source of dust dominated by quartz, oxihydroxides, and feldspars [Claquin et al., 1999; Gao et al., 2003]. The presence of concordant $\sim 640$ Ma old zircons in the Sirius Passet mudstones suggests that Pan-African collisions promoted the rise of cold arid plateaus similar to modern Tibet. Wind-blown particles are known to bring iron oxihydroxide to the oceans and thereby to increase overall productivity [Martin, 1990]. Stronger fluxes of wind-blown particles also increase sinking rate of organic matter and reduce organic matter regeneration (the so-called ballast effect) [Francois et al., 2002]. As desert dust also has a very strong action on the carbon cycle and climate [Jickells et al., 2005], we believe that the eolian flavor of the Sirius Passet Lagerstätte sediments illustrates how the rapid fluctuations of the $\delta^{13} \mathrm{C}$ cycles during the Cambrian and the Cambrian Explosion may be connected via geodynamic forcing of atmospheric circulation and ocean productivity.

\section{Conclusions}

The combination of major and trace element data and S, C, Fe, Zn, and Mo isotope compositions on a $8 \mathrm{~m}$ thick section of the Cambrian Sirius Passet Lagerstätte led to the following main conclusions:

1. The lithology of the mudstone can be broken down into variable proportions of two inputs, a dry felsic component and a hydrous mafic component (smectite and/or chlorite). The protolith was a soil formed at low latitudes.

2. The diagenetic transformations correspond to well-established sequences of reactions between solid phases and interstitial solutions. They involve reduction of $S$ from seawater and of Fe and Mo from hydroxides and ensuing pyritization.

3. There is no clear indication in the metal geochemistry that the overlying water column was anoxic, hypoxic, or euxinic. The fluctuating oxycline model does not explain the low $\mathrm{P}$ contents of the rocks.

4. The fossiliferous layers of the Lagerstätte therefore represent oxygen-starved muds inhospitable to life underlying a well-ventilated water column.

5. The oxygen status in the benthic boundary layer and the sediment-water interface is not constrained by any geochemical observations, but only in the presence of the fauna.

The climatic, tectonic, or erosional factors alone do not account for the prevalence of Cambrian Lagerstätten nor their distribution as a small number of short pulses $(<2 \mathrm{Ma})$. The chemistry and the very fine grain size of the samples and the lack of graded bedding suggest that the Sirius Passet Lagerstätte is best explained as a sequence containing a contribution from marine eolian dust. 


\section{Acknowledgments}

We would like to thank Galen Halverson and anonymous reviewers for comments that helped improve the manuscript. Financial support through the Carlsberg Foundation, the Programme National de Planetology (Institut National des Sciences de I'Univers), and the INSU program of support to the French National Facilities is gratefully acknowledged. Help in the laboratory from Florent Arnaud-Godet, Ghislaine Broillet, Emmanuelle Albalat, and Janne Blichert-Toft, and at the ICP-MS from Philippe Télouk made this work possible.

\section{References}

Albarède, F. (2004), The stable isotope geochemistry of copper and zinc, in Geochemistry of Non-Traditional Stable Isotopes, Reviews in Mineralogy and Geochemistry, edited by C. M. Johnson, B. L. Beard, and F. Albarède, pp. 409-427, Mineral. Soc. of Am., Washington, D. C.

Allègre, C. J. and E. Lewin (1995), Scaling laws and geochemical distributions, Earth Planet. Sci. Letters, 132(1-4), 1-13.

Allison, P. A., and D. E. G. Briggs (1993), Exceptional fossil record: Distribution of soft-tissue preservation through the Phanerozoic, Geology, 21(6), 527-530.

Allison, P. A., and C. E. Brett (1995), In-situ benthos and paleo-oxygenation in the Middle Cambrian Burgess Shale, British-Columbia, Canada, Geology, 23, 1079-1082.

Babcock, L. E., and J. S. Peel (2007), Palaeobiology, taphonomy and stratigraphic significance of the trilobite BUENELLUS from the Sirius Passet Biota, Cambrian of North Greenland, Mem. Assoc. Aust. Palaeontol., 34, 401-418.

Barling, J., G. L. Arnold, and A. D. Anbar (2001), Natural mass-dependent variations in the isotopic composition of molybdenum, Earth Planet. Sci. Lett., 193(3-4), 447-457.

Barnes, R. O., and E. D. Goldberg (1976), Methane production and consumption in anoxic marine sediments, Geology, 4(5), $297-300$.

Bennett, R. H., B. Ransom, M. Kastner, R. J. Baerwald, M. H. Hulbert, W. B. Sawyer, H. Olsen, and M. W. Lambert (1999), Early diagenesis: Impact of organic matter on mass physical properties and processes, California continental margin, Mar. Geol., 159(1-4), 7-34.

Bergquist, B. A., and E. A. Boyle (2006), Iron isotopes in the Amazon River system: Weathering and transport signatures, Earth Planet. Sci. Lett., 248(1-2), 54-68.

Berner, R. A. (1980), Early Diagenesis: A Theoretical Approach, Princeton Univ. Press, Princeton, N. J.

Blaker, M. R., and J. S. Peel (1997), Lower Cambrian Trilobites from North Greenland, Meddelelser om Grønland, Geoscience, 35: 1-145. doi: 10.1016/j.palaeo.2007.05.023.

Bostick, B. C., S. Fendorf, and G. R. Helz (2002), Differential adsorption of molybdate and tetrathiomolybdate on pyrite $\left(\mathrm{FeS}_{2}\right)$, Environ. Sci. Technol., 37(2), 285-291.

Briggs, D. E. G. (1981), The arthropod Odaraia alata Walcott, Middle Cambrian, Burgess Shale, British Columbia, Philos. Trans. R. Soc. London, Ser. B, 291(1056), 541-582.

Burton, E. A., and L. M. Walter (1990), The role of $\mathrm{pH}$ in phosphate inhibition of calcite and aragonite precipitation rates in seawater, Geochim. Cosmochim. Acta, 54(3), 797-808.

Butterfield, N. J. (2002), Leanchoilia guts and the interpretation of three-dimensional structures in Burgess Shale-type fossils, Paleobiology, 28(1), 155-171.

Cai, Y., J. D. Schiffbauer, H. Hua, and S. Xiao (2012), Preservational modes in the Ediacaran Gaojiashan Lagerstätte: Pyritization, aluminosilicification, and carbonaceous compression, Palaeogeogr. Palaeoclimatol. Palaeoecol., 326-328, 109-117.

Calvert, S. E., and N. B. Price (1977), Geochemical variation in ferromanganese nodules and associated sediments from the Pacific Ocean, Mar. Chem., 5(1), 43-74.

Canfield, D. E. (1989), Reactive iron in marine sediments, Geochim. Cosmochim. Acta, 53(3), 619-632.

Claquin, T., M. Schulz, and Y. J. Balkanski (1999), Modeling the mineralogy of atmospheric dust sources, J. Geophys. Res., 104(D18), 22,243$22,256$.

Cocks, L. R. M., and T. H. Torsvik (2011), The Palaeozoic geography of Laurentia and western Laurussia: A stable craton with mobile margins, Earth Sci. Rev., 106(1-2), 1-51.

Derry, L. A., M. D. Brasier, R. M. Corfield, A. Y. Rozanov, and A. Y. Zhuravlev (1994), Sr and C isotopes in Lower Cambrian carbonates from the Siberian craton: A paleoenvironmental record during the 'Cambrian explosion', Earth Planet. Sci. Lett., 128(3), 671-681.

Erickson, B. E., and G. R. Helz (2000), Molybdenum(VI) speciation in sulfidic waters: Stability and lability of thiomolybdates, Geochim. Cosmochim. Acta, 64(7), 1149-1158.

Escoube, R., O. J. Rouxel, E. Sholkovitz, and O. F. X. Donard (2009), Iron isotope systematics in estuaries: The case of North River, Massachusetts (USA), Geochim. Cosmochim. Acta, 73(14), 4045-4059.

Fantle, M. S., and D. J. DePaolo (2004), Iron isotopic fractionation during continental weathering, Earth Planet. Sci. Lett., 228(3-4), 547-562.

Francois, R., S. Honjo, R. Krishfield, and S. Manganini (2002), Factors controlling the flux of organic carbon to the bathypelagic zone of the ocean, Global Biogeochem. Cycles, 16(4), 1087

Froelich, P. N., G. P. Klinkhammer, M. L. Bender, N. A. Luedtke, G. R. Heath, D. Cullen, P. Dauphin, D. Hammond, B. Hartman, and V. Maynard (1979), Early oxidation of organic matter in pelagic sediments of the eastern equatorial Atlantic: Suboxic diagenesis, Geochim. Cosmochim. Acta, 43(7), 1075-1090.

Fujii, T., and F. Albarède (2012), Ab initio calculation of the $\mathrm{Zn}$ isotope effect in phosphates, citrates, and malates and applications to plants and soil, PLoS One, 7(2), e30726.

Fujii, T., F. Moynier, M. Abe, K. Nemoto, and F. Albarède (2013), Copper isotope fractionation between aqueous compounds relevant to low temperature geochemistry and biology, Geochim. Cosmochim. Acta, 110, 29-44.

Gaines, R., and M. L. Droser (2005), New approaches to understanding the mechanics of Burgess Shale-type deposits: From the micron scale to the global picture, Sediment. Rec., 3(2), 4-8.

Gaines, R. R., and M. L. Droser (2010), The paleoredox setting of Burgess Shale-type deposits, Palaeogeogr. Palaeoclimatol. Palaeoecol. 297(3-4), 649-661.

Gaines, R. R., M. J. Kennedy, and M. L. Droser (2005), A new hypothesis for organic preservation of Burgess Shale taxa in the middle Cambrian Wheeler Formation, House Range, Utah, Palaeogeogr. Palaeoclimatol. Palaeoecol., 220(1-2), 193-205.

Gaines, R. R., E. U. Hammarlund, X. Hou, C. Qi, S. E. Gabbott, Y. Zhao, J. Peng, and D. E. Canfield (2012), Mechanism for Burgess Shale-type preservation, Proc. Natl. Acad. Sci. U. S. A., 109(14), 5180-5184.

Gao, Y., S. M. Fan, and J. L. Sarmiento (2003), Aeolian iron input to the ocean through precipitation scavenging: A modeling perspective and its implication for natural iron fertilization in the ocean, J. Geophys. Res., 108(D7), 4221, doi:10.1029/2002JD002420.

Gehling, J. G. (1999), Microbial mats in terminal Proterozoic siliciclastics: Ediacaran death masks, Palaios, 14(1), 40-57.

Goldberg, T., C. Archer, D. Vance, and S. W. Poulton (2009), Mo isotope fractionation during adsorption to Fe (oxyhydr) oxides, Geochim. Cosmochim. Acta, 73(21), 6502-6516.

Helly, J. J., and L. A. Levin (2004), Global distribution of naturally occurring marine hypoxia on continental margins, Deep Sea Res., Part I, 51(9), 1159-1168.

Helz, G. R., C. V. Miller, J. M. Charnock, J. F. W. Mosselmans, R. A. D. Pattrick, C. D. Garner, and D. J. Vaughan (1996), Mechanism of molybdenum removal from the sea and its concentration in black shales: EXAFS evidence, Geochim. Cosmochim. Acta, 60(19), 3631-3642. 
Higgins, A. K., J. R. Ineson, J. S. Peel, F. Surlyk, and M. Sønderholm (1991), Lower Palaeozoic Franklinian Basin of North Greenland, in Sedimentary Basins of North Greenland, edited by J. S. Peel and M. Sønderholm, Grønlands Geologiske Undersøgelse, Bulletin 160. pp. 71-139.

Hoffman, P. F. (1991), Did the breakout of Laurentia Turn Gondwanaland inside-out?, Science, 252(5011), 1409-1412.

Hurst, J. M., and F. Surlyk (1983), Initiation, evolution, and destruction of an early Paleozoic carbonate shelf, eastern North Greenland, J. Geol., 91(6), 671-691.

lizuka, T., I. H. Campbell, C. M. Allen, J. B. Gill, S. Maruyama, and F. Makoka (2013), Evolution of the African continental crust as recorded by $\mathrm{U}-\mathrm{Pb}$, Lu-Hf and O isotopes in detrital zircons from modern rivers, Geochim. Cosmochim. Acta, 107, 96-120.

Ineson, J. R., and J. S. Peel (1997), Cambrian shelf stratigraphy of North Greenland, Geol. Greenl. Surv. Bull., 173, 120 pp.

Ineson, J. R., and J. S. Peel (2011), Geological and depositional setting of the Sirius Passet Lagerstätte (Early Cambrian), North Greenland, Can. J. Earth Sci., 48(8), 1259-1281.

Jacobs, L., S. Emerson, and S. S. Huested (1987), Trace metal geochemistry in the Cariaco Trench, Deep Sea Res., Part A, 34(5-6), 965-981. Jickells, T. D., et al. (2005), Global iron connections between desert dust, ocean biogeochemistry, and Climate, Science, 308(5718), 67-71. Johnson, R. A., and D. W. Wichern (1992), Applied Multivariate Statistical Analysis, 594 pp., Prentice Hall, Englewood Cliffs, N. J.

Jones, B., and D. A. C. Manning (1994), Comparison of geochemical indices used for the interpretation of palaeoredox conditions in ancient mudstones, Chem. Geol., 111(1-4), 111-129.

Kusky, T. M., M. Abdelsalam, R. D. Tucker, and R. J. Stern (2003), Evolution of the East African and related orogens, and the assembly of Gondwana, Precambrian Res., 123(2-4), 81-85.

Lagebro, L., M. Stein, and J. S. Peel (2009), A new?lamellipedian arthropod from the early Cambrian Sirius Passet Fauna of North Greenland J. Paleontol., 83(5), 820-825.

Lehmann, B., T. F. Nägler, H. D. Holland, M. Wille, J. Mao, J. Pan, D. Ma, and P. Dulski (2007), Highly metalliferous carbonaceous shale and Early Cambrian seawater, Geology, 35(5), 403-406.

Leventhal, J., and C. Taylor (1990), Comparison of methods to determine degree of pyritization, Geochim. Cosmochim. Acta, 54(9), 2621-2625.

Levin, L. A. (2003), Oxygen minimum zone benthos: Adaptation and community response to hypoxia, Oceanogr. Mar. Biol., 41, 1-45.

Li, Z. X., et al. (2008), Assembly, configuration, and break-up history of Rodinia: A synthesis, Precambrian Res., 160(1-2), 179-210.

Londry, K. L., and D. J. Des Marais (2003), Stable carbon isotope fractionation by sulfate-reducing bacteria, Appl. Environ. Microbiol., 69(5), 2942-2949.

Luo, H., S. Hu, S. Zhang, and Y. Tao (1997), New occurrence of the Early Cambrian Chengjiang Fauna in Haikou, Kunming, Yunnan Province, and study on Trilobitoidea, Acta Geol. Sin., 71(2), 122-132.

Lyons, T. W., and S. Severmann (2006), A critical look at iron paleoredox proxies: New insights from modern euxinic marine basins, Geochim. Cosmochim. Acta, 70(23), 5698-5722.

Lyons, T. W., A. D. Anbar, S. Severmann, C. Scott, and B. C. Gill (2009), Tracking Euxinia in the Ancient Ocean: A multiproxy perspective and proterozoic case study, Annu. Rev. Earth Planet. Sci., 37(1), 507-534.

Maloof, A. C., S. M. Porter, J. L. Moore, F. Ã. DudÃ $j$ s, S. A. Bowring, J. A. Higgins, D. A. Fike, and M. P. Eddy (2010), The earliest Cambrian record of animals and ocean geochemical change, Geol. Soc. Am. Bull., 122(11-12), 1731-1774.

Mangano, M. G., R. G. Bromley, D. A. T. Harper, A. T. Nielsen, M. P. Smith, and J. Vinther (2012), Nonbiomineralized carapaces in Cambrian seafloor landscapes (Sirius Passet, Greenland): Opening a new window into early Phanerozoic benthic ecology, Geology, 40(6), 519-522.

Maréchal, C. N., P. Télouk, and F. AlbarÄ̈de (1999), Precise analysis of copper and zinc isotopic compositions by plasma-source mass spectrometry, Chem. Geol., 156(1-4), 251-273.

Martin, J. H. (1990), Glacial-interglacial $\mathrm{CO}_{2}$ change: The Iron Hypothesis, Paleoceanography, 5(1), 1-13.

McCausland, P. J. A., R. Van der Voo, and C. M. Hall (2007), Circum-lapetus paleogeography of the Precambrian-Cambrian transition with a new paleomagnetic constraint from Laurentia, Precambrian Res., 156(3-4), 125-152.

McKerrow, W. S., C. R. Scotese, and M. D. Brasier (1992), Early Cambrian continental reconstructions, J. Geol. Soc., 149(4), 599-606.

McKirdy, D. M., P. A. Hall, C. Nedin, G. P. Halverson, B. H. Michaelsen, J. B. Jago, J. G. Gehling, and R. J. F. Jenkins (2011), Paleoredox status and thermal alteration of the lower Cambrian (series 2) Emu Bay Shale Lagerstätte, South Australia, Aust. J. Earth Sci., 58(3), 259-272.

McLennan, S. M., S. R. Taylor, and K. A. Eriksson (1983), Geochemistry of Archean shales from the Pilbara Supergroup, Western Australia, Geochim. Cosmochim. Acta, 47(7), 1211-1222.

Meert, J. G. (2003), A synopsis of events related to the assembly of eastern Gondwana, Tectonophysics, 362(1-4), 1-40.

Morford, J. L., and S. Emerson (1999), The geochemistry of redox sensitive trace metals in sediments, Geochim. Cosmochim. Acta, 63(11-12) $1735-1750$.

Morris, S. C. (1986), The community structure of the Middle Cambrian phyllopod bed(Burgess Shale), Palaeontology, 29(3), 423-467

Morris, S. C., J. S. Peel, A. K. Higgins, N. J. Soper, and N. C. Davis (1987), A Burgess shale-like fauna from the Lower Cambrian of North Greenland, Nature, 326(6109), 181-183.

Nedin, C. (1995), The palaeontology and palaeoenvironment of the Early Cambrian Emu Bay Shale, Kangaroo Island, South Australia, PhD thesis, Univ. of Adelaide, Adelaide, South Australia.

Nesbitt, H. W., and G. M. Young (1982), Early Proterozoic climates and plate motions inferred from major element chemistry of lutites, Nature, 299(5885), 715-717.

Nesbitt, H. W., and G. M. Young (1989), Formation and diagenesis of weathering profiles, J. Geol., 97(2), 129-147.

Nutman, A. P., P. R. Dawes, F. Kalsbeek, and M. A. Hamilton (2008), Palaeoproterozoic and Archaean gneiss complexes in northern Greenland: Palaeoproterozoic terrane assembly in the High Arctic, Precambrian Res., 161(3-4), 419-451.

Peel, J. S. (2010), A corset-like fossil from the Cambrian Sirius Passet Lagerstätte of North Greenland and its implications for cycloneuralian evolution, J. Paleontol., 84(2), 332-340.

Peel, J. S., and J. R. Ineson (2011), The extent of the Sirius Passet Lagerstätte (early Cambrian) of North Greenland, Bull. Geosci., 86(3), 535-543.

Petrovich, R. (2001), Mechanisms of fossilization of the soft-bodied and lightly armored faunas of the Burgess Shale and of some other classical localities, Am. J. Sci., 301(8), 683-726.

Piper, D. Z. (1988), The metal oxide fraction of pelagic sediment in the equatorial North Pacific Ocean: A source of metals in ferromanganese nodules, Geochim. Cosmochim. Acta, 52(8), 2127-2145.

Plank, T., and C. H. Langmuir (1998), The chemical composition of subducting sediment and its consequences for the crust and mantle, Chem. Geol., 145(3-4), 325-394.

Pons, M. L., G. Quitté, T. Fujii, R. M.T., B. Reynard, F. Moynier, C. Douchet, and F. Albarede (2011), Early Archean serpentine mud volcanoes at Isua, Greenland, as a niche for early life, Proc. Natl. Acad. Sci. U. S. A., 108, 17,639-17,643. 
Powell, W. G., P. A. Johnston, and C. J. Collom (2003), Geochemical evidence for oxygenated bottom waters during deposition of fossiliferous strata of the Burgess Shale Formation, Palaeogeogr. Palaeoclimatol. Palaeoecol., 201(3-4), 249-268.

Raiswell, R., D. E. Canfield, and R. A. Berner (1994), A comparison of iron extraction methods for the determination of degree of pyritisation and the recognition of iron-limited pyrite formation, Chem. Geol., 111(1-4), 101-110.

Rea, D. K. (1994), The paleoclimatic record provided by eolian deposition in the deep sea: The geologic history of wind, Rev. Geophys., 32(2), 159-195.

Reeburgh, W. S., and D. T. Heggie (1974), Depth distributions of gases in shallow water sediments, in Natural Gases in Marine Sediments, edited by I. R. Kaplan, pp. 27-45, Plenum, New York, N.Y.

Rhoads, D. C., and J. W. Morse (1971), Evolutionary and ecologic significance of oxygen deficient marine basins, Lethaia, 4(4), 413-428.

Rino, S., Y. Kon, W. Sato, S. Maruyama, M. Santosh, and D. Zhao (2008), The Grenvillian and Pan-African orogens: World's largest orogenies through geologic time, and their implications on the origin of superplume, Gondwana Res., 14(1-2), 51-72.

Scott, C., and T. W. Lyons (2012), Contrasting molybdenum cycling and isotopic properties in euxinic versus non-euxinic sediments and sedimentary rocks: Refining the paleoproxies, Chem. Geol., 324-325, 19-27.

Seilacher, A., W. E. Reif, F. Westphal, R. Riding, E. N. K. Clarkson, and H. B. Whittington (1985), Sedimentological, ecological and temporal patterns of fossil Lagerstatten [and Discussion], Philos. Trans. R. Soc. London, Ser. B, 311(1148), 5-24.

Siebert, C., T. F. Nägler, and J. D. Kramers (2001), Determination of molybdenum isotope fractionation by double-spike multicollector inductively coupled plasma mass spectrometry, Geochemist. Geophys. Geosyst., 2(7), 1032.

Siebert, C., T. F. Nägler, F. von Blanckenburg, and J. D. Kramers (2003), Molybdenum isotope records as a potential new proxy for paleoceanography, Earth Planet. Sci. Lett., 211(1-2), 159-171.

Steiner, M., M. Zhu, Y. Zhao, and B.-D. Erdtmann (2005), Lower Cambrian Burgess Shale-type fossil associations of South China, Palaeogeogr. Palaeoclimatol. Palaeoecol., 220(1-2), 129-152.

Stramma, L., G. C. Johnson, J. Sprintall, and V. Mohrholz (2008), Expanding oxygen-minimum zones in the tropical oceans, Science, $320(5876), 655-658$.

Stramma, L., S. Schmidtko, L. A. Levin, and G. C. Johnson (2010), Ocean oxygen minima expansions and their biological impacts, Deep Sea Res., Part I, 57(4), 587-595.

Surlyk, F., and J. R. Ineson (1987), Aspects of Franklinian shelf, slope and trough evolution and stratigraphy in North Greenland, Rapp. Grønlands Geol. Unders., 133, 41-58.

Taylor, S. R., and S. M. McLennan (1985), The Continental Crust: Its Composition and Evolution, Blackwell Sci., Palo Alto, Calif.

Tossell, J. A. (2005), Calculating the partitioning of the isotopes of Mo between oxidic and sulfidic species in aqueous solution, Geochim. Cosmochim. Acta, 69(12), 2981-2993.

Tribovillard, N., A. Riboulleau, T. Lyons, and F. O. Baudin (2004), Enhanced trapping of molybdenum by sulfurized marine organic matter of marine origin in Mesozoic limestones and shales, Chem. Geol., 213(4), 385-401.

Tribovillard, N., T. J. Algeo, T. Lyons, and A. Riboulleau (2006), Trace metals as paleoredox and paleoproductivity proxies: An update, Chem. Geol., 232(1-2), 12-32.

Whitehouse, M. J., and B. S. Kamber (2005), Assigning dates to thin gneissic veins in high-grade metamorphic terranes: A cautionary tale from Akilia, Southwest Greenland, J. Petrol., 46(2), 291-318.

Whitmeyer, S. J., and K. E. Karlstrom (2007), Tectonic model for the Proterozoic growth of North America, Geosphere, 3(4), $220-259$.

Xiao, J., S. C. Porter, Z. An, H. Kumai, and S. Yoshikawa (1995), Grain size of quartz as an indicator of winter monsoon strength on the loess plateau of central China during the Last 130,000 Yr, Quat. Res., 43(1), 22-29.

Xu, L., B. Lehmann, J. Mao, T. F. Nägler, N. Neubert, M. E. Boettcher, and P. Escher (2012), Mo isotope and trace element patterns of Lower Cambrian black shales in South China: Multi-proxy constraints on the paleoenvironment, Chem. Geol., 318-319(0), 45-59.

Zhang, W.-T., and X.-G. Hou (1985), Preliminary notes on the occurrence of the unusual trilobite Naraoia in Asia, Acta Paleontol. Sin., 24(6), 591-595.

Zhang, X.-G., and X.-G. Hou (2007), Gravitational constraints on the burial of Chengjiang fossils, Palaios, 22(4), 448-453.

Zhang, X.-G., X.-G. Hou, and J. A. N. BergstrÃ-M (2006), Early Cambrian priapulid worms buried with their lined burrows, in Geological Magazine, edited, pp. 743-748, Cambridge Univ. Press, Cambridge, U. K.

Zhu, M.-Y., L. E. Babcock, and S.-C. Peng (2006), Advances in Cambrian stratigraphy and paleontology: Integrating correlation techniques, paleobiology, taphonomy and paleoenvironmental reconstruction, Palaeoworld, 15(3-4), 217-222. 